\title{
På sporet av et mangfold av friluftslivsstiler
}

\section{Af Kirsti Pedersen}

Avdeling for fritids- og kulturfag, Høgskolen i Finnmark, Alta ${ }^{1}$

1993 var Friluftslivets år i Norge. Denne markeringen av friluftslivets betydning i norsk kultur og hverdagsliv, falt sammen med feiringen av Den norske turistforenings 125 års jubileum. Dette sammenfallet er ikke tilfeldig. Den norske turistforening og utviklingen av fjellturismen som denne foreningen har fremmet, er nettopp knyttet til sterke symboler på norskhet. I løpet av året ble friluftsliv som et særlig uttrykk for norsk kultur hyldet i forskjellige sammenhenger, samtidig som friluftslivet ble analysert og drøftet i vitenskapelige rapporter og på konferanser. Både innen forskning og forvaltning kommer det ofte til uttrykk oppfatninger som synes å bygge på den forståelse at det finnes et enhetlig norsk friluftsliv. Med utgangspunkt i en studie av kjønnsrelasjoner i friluftsliv basert på feltarbeid i et lokalsamfunn lengst nord i Norge, i Finnmark ${ }^{2}$, vil jeg forsøke å underbygge en hypotese om kulturelt mangfold og variasjon. Ved å ta utgangspunkt i folkelige praksiser, erfaringer og opplevelser kommer en på sporet av kulturelle forskjeller som både kan knyttes til forskjeller mellom kjønnene, mellom generasjoner, mellom livsformer, og til etnisk og regional tilhørighet. Studiet av tur- og friluftsliv i 1990-årenes Finnmark viser et empirisk mangfold der lokale høstingstradisjoner omformes i møtet med det »nasjonale vandrerfriluftslivet « og internasjonale trender der teknologi og naturturisme spil- ler inn (Pedersen 1993a, Pedersen og Viken under utgivelse). I Finnmarksnaturen møter vi grupper av kvinner og menn som beveger seg i forskjellige kulturelle - om enn i samme geografiske landskap: For den samiske befolkningen og for den »vanlige « finnmarking er havet, fjæra, elvene og vidda verken eksotisk eller fremmed. Utmarka er først og fremst produksjonslandskaper; vedskog, jaktmarker, fiske-

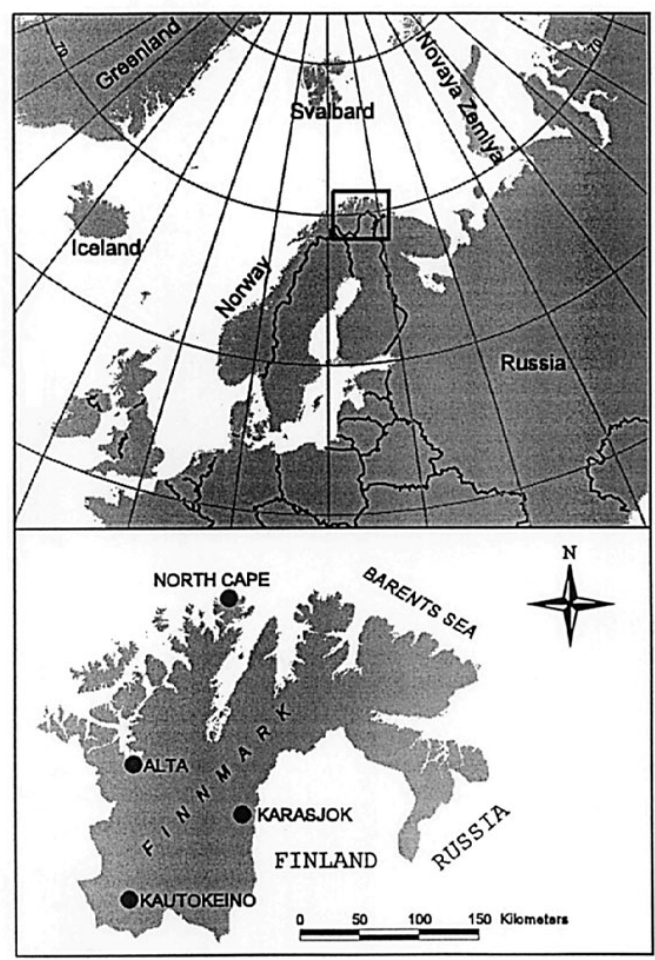

Fig. 1 . 
vann og bærmyrer. Men det er også et kulturlandskap som bærer spor etter formødrenes og -fedrenes liv og ferdsel. Tilflytteren og turisten beveger seg oftere $\mathrm{i}$ »Europas siste villmark «; i fritids- og rekreasjonslandskapet. I det sen-moderne Finnmark, i »den globale utkanten«, eksisterer det - dels parallelt, dels i konflikt med hverandre, et mangfold av friluftslivsstiler. Både enkelt- og gruppevis innebærer moderniteten større handlingsfrihet og $\varnothing$ kte muligheter for fristilling i forhold til sosial og kulturell bakgrunn. Endringer i kvinneroller og i forholdet mellom kjønnene utfordrer et tradisjonelt kjønnsdelt mønster i bruk av naturen (Pedersen 1992, 1994). For friluftslivsforskningen er det en utfordring å utvikle kunnskap om forskjellige grupper av kvinners og menns forhold til friluftsliv; å utvikle en flerdimensjonal forståelse av kategoriene kvinnelighet og mannlighet, såvel som av begrepet om den nasjonale turkulturen.

\section{Myten om \\ »Den norske turkulturen«}

En landsrepresentativ undersøkelse av det norske folks fritidsvaner, den såkalte $F A$ FO-undersøkelsen fra $1987^{3}$, slår fast at norske kvinner og menn er tradisjonalister: Det er turkulturen som dominerer fritidsbildet. I fritida går det norske folk helst på turer i skog og mark, samtidig som vi ønsker å gjøre mer av det samme om vi hadde mer fri og ubunden tid (Dølvik m.fl. 1988). En lignende undersøkelse, gjennomført på oppdrag for Friluftslivets fellesorganisasjon $^{4}$ i forbindelse med Friluftslivets år 1993, FRIFO-undersøkelsen, viser et lignende resultat: Det å gå på tur uten et materielt nytteformål dominerer. Enigheten i befolkningen er i følge denne unders $ø$ kelsen også stor når det gjelder hvorfor folk drar på tur. Folks egne forklaringer knytter seg først og fremst til kontemplative verdier: Gjennom turer i skog og mark søker norske kvinner og menn naturens stillhet og ro, de ønsker å komme ut i frisk luft, vekk fra støy og forurensning, mas og stress. Dernest søker det norske folk sosiale verdier som det å være sammen med familie og venner gjennom friluftsliv. Sett fra en idrettsfaglig synsvinkel er det interessant at først på tredje plass rangerer folk den betydningen turgåing har for det å komme i bedre fysisk form. Videre er det så få som søker ut i naturen for å »sette sine evner til å mestre vanskelige eller slitsomme situasjoner på prøve«, eller for å »oppleve spenning ved å bestige topper eller gå $i$ krevende eller farlig terreng ", at de ikke gjør utslag i FRIFO-unders $\emptyset$ kelsen (Vaagbø 1993:9). Høsting av bær og sopp, samt jakt og fiske har for gjennomsnittsbefolkningen minimal betydning som drivkraft for vandringer i naturen, selv om det er mange som har vært på en eller noen få bær- eller fisketurer i løpet av et år (Dølvik m fl 1988, Vaagbø 1993). Disse landsdekkende undersøkelsene viser altså at vandringer i friluft er en viktig kilde til meditasjon og avstressing i en hektisk hverdag: Det norske folk vandrer inn i naturen, og samtidig inn i seg selv. FRIFO-unders $ø$ kelsens konklusjon er at det bildet som framkommer av friluftsliv er så entydig og enhetlig at det kan karakteriseres som Den norske turkulturen (Vaagbø 1993).

Friluftslivets status som et særdeles viktig innslag i norsk kultur og samfunnsliv kommer også til uttrykk gjennom det offentlige lovverket og i politiske dokumenter; for eksempel i »Friluftsloven « av 1957, Finansdepartementets langtidsprogram; Spesialanalyse om friluftsliv (197273) og Stortingsmelding nr. 40: Om friluftsliv (Miljøverndepartementet 1987). 
Den norske turistforening (1993:6) hevder for eksempel i strateginotatet $»$ Friluftsliv og glede « at foreningen forvalter »den norske turkulturen« og idealene om »det enkle turliv« i nærkontakt med uberørt natur.

Flere samfunnsvitere (for eksempel Skirbekk 1982, Østerberg 1984, Nedrelid 1988, 1991, 1992, Gullestad 1990, Aarnes 1991, Witoszek 1991) har med utgangspunkt i allmenne studier av det norske samfunnet, de siste årene fattet interesse for friluftsliv og det norske folks nærhet til naturen. Noen tolker den norske søndagsturen som et rituale mange utfører eller i det minste synes at de bør utføre - nærmest som en religiøs og moralsk forpliktende handling. Andre tolkninger legger vekt på at begrepet natur står sterkere i norsk bevissthet enn begrepet kultur. En hovedtrend går ut på å undersøke friluftslivets betydning for nordmenns nasjonale identitet - å vise hvordan friluftsliv er et særnorsk fenomen som konstituerer hva det vil si å være norsk. Denne særegne norske opptatthet av naturen blir som oftest ført tilbake til norsk selvstendiggjøring fra dansk og svensk herredømme, og hvordan norske fjell, daler og bondekultur, så vel som polarheltenes ensomme kamp for å overleve i samspill med barsk natur, ble viktige symbol i danningen av den norske nasjonalstaten. Aarnes (1991) beskriver dette slik:

»Når noen fremtredende Kristiania-borgere omkring 1860 begynner å dra på årvisse turer i fjellet, er vel det nærmeste forbildet den britiske leisure class' innvadering av det skotske høylandet eller de sveitsiske alper. (...) Da den norske fjellturismen ble til, har vi altså ikke å gjøre med en slags nøytral interesse for mosjon - en joggebølge for hundre år siden - men med en særgen romantisk dyrkelse av »det nasjonale«. (Aarnes 1991:79-81).«

Også forskere og pedagoger/veiledere som mer direkte tar utgangspunkt i forskning om idrett og friluftsliv er opptatt av den rollen friluftsliv har spilt i nasjonsbyggingsprosessen og den rolle det spiller i dagens norske samfunn (Faarlund 1987, Goksøyr 1994). Her legges det vekt på ferdsel og opphold $\mathrm{i}$ »uberørt« natur, på en trang til å oppsøke ensomheten og til å mestre utfordringene på egenhånd (Goksøyr 1994). Dessuten, $\gg$ Det er naturopplevelsen som er friluftslivets kjerne. Og opplevelsen blir til $i$ spenningsfeltet mellom utfordring og opplevelse.« (Faarlund 1987:18-19). I følge Richardson (1994) er de tre mest markerte verdiene i det norske friluftslivet vektleggingen av det enkle utstyret, den enkle tilretteleggingen og mestringen av det fysiske slitet. Beherskelsen av de fysiske utfordringene må imidlertid skje på en verdig og »mesterlig måte «:

»Å være norsk sto jo for å være hjemme i den slags natur som teknikken ikke hadde satt sine spor i. Det ville altså si å kjenne den frie naturs væremåte været, lendet, sjøen - og samtidig å kunne te seg mesterlig der. (Faarlund 1987:17).«

Denne måten å forstå friluftsliv på legger vekt på å videreføre arven etter de første mannlige vitenskapsmennene og kunstnerne, »oppdagerne « og erobrerne av den norske fjellheimen - de som dyrket villmarksromantikkens interesse for ur-naturen - for det $\varnothing$ de og dramatiske, for tinder og topper. Ett annet utgangspunkt for den nasjonalitetsorienterte friluftslivsforskningen, er den som viderefører arven etter de første folkelivsgranskernes og eventyrsamlernes interesse for »å lære landet og folkelivet å kjenne«. Framveksten av friluftsliv og naturoppfatninger i det moderne samfunnet kobles til livet i det tradisjonelle bondesamfunnet, til endringer i lokalsamfunn og livsformer (Klepp og Thorsen red. 1993). I denne forskningen står tradisjonsperspektivet sterkt. Det er et perspektiv som framhe- 
ver kontinuitet som det bærende utviklingsprinsipp, og som bygger på en forståelse av endring som noe som skjer sakte og gradvis, og i nær forhandling med det bestående. I et slikt perspektiv er det ikke den »uberørte « naturen og »det gode slitet « som står i fokus, men den naturen som er et resultat av samspillet mellom menneske og natur; kulturlandskapet.

Et felles utgangspunkt for de to tilnærmingene er fortolkningen av friluftsliv som byborgerskapets - og senere byfolks - behov for rekreasjon og naturopplevelser. Den dominerende fortolkningen av friluftslivets historiske utvikling hevder at den klassespesifikke turkulturen »folkeliggjøres « ved at både bønder, fiskere og arbeidere gradvis overtar byborgerskapets »overskuddsliv« (Nedrelid 1992, Goksøyr 1994). Framveksten av friluftsliv eller fritid i friluft som et massefenomen i etterkrigstidas Norge beskriver for eksempel Frislid (1983) som en allmenn utvikling, mens Aarnes (1991) kaller det en demokratiseringsprosess. Goksøyr (1994:187) hevder med utgangspunkt i en studie av framveksten av moderne idrett og friluftsliv i Bergen på 1800-tallet at

»Heller enn å bli sosialisert inn i en dominerende klasses kultur, overtok vanlige folk noe som både ble oppfattet som positivt og faktisk virket befriende for mennesker som ellers var $\mathrm{d} \varnothing \mathrm{mt}$ til å tilbringe livet $\mathrm{i}$ larmende fabrikker, trafikkerte gater og trangbodde leiligheter«. Nedrelid (1992:28) legger vekt på at »...,it is a fact that the bourgeoisie taught the rest of the population that we had a country that was worth seeing, and that this could be used for pleasure and recreation.«

Den nasjonalitetsorienterte forskningen kan imidlertid kritiseres for å være myteunderbyggende fordi den støtter opp om en forestilling om at nordmenn i det gamle bondesamfunnet levde i så ugjestmild natur at $» v i \ll$ har fått et spesielt eksistensielt forhold til den norske naturen (Richardson 1994)5. Samtidig kan den kritiseres for å underkommunisere iboende motsetninger i friluftsliv og i det norske samfunnet. Mens byborgerskapet henter inspirasjon $» u t e n-$ fra « - fra romantiske strømninger i det europeiske kulturliv, er det fjellbøndene som »fører « dem inn i den »ukjente« og »uoppdagede« norske fjellheimen. Den nevnte læreprosessen har altså neppe vært en enveisprossess. Det har snarere skjedd en utveksling av kunnskap, men slik at byborgeren og fjellbondens læring var av kvalitativt forskjellig karakter. Fjellbøndenes livsformer blir av det framvoksende borgerskapet romantisert og mytologisert slik at det passer med de borgerlige ideene som er i ferd med å vokse fram rundt århundreskiftet. Det harde arbeidet i fjellheimen foredler mennesket, og formidler et bilde av naturlig norskhet som egnet seg godt når det nasjonale fellesskapet trengte en markering. Gjennom en analyse av Den norske turistforenings årbøker i perioden 18681993 tydeliggjør Richardson (1994) blant annet klasseperspektivet i fjellfriluftslivet idet hun viser hvordan borgerskapets dannelsesreiser utvikler seg til fjellturisme, som igjen danner mål for friluftsliv som massekultur. Hun viser hvordan friluftsliv inngår i en mer eller mindre bevisst kamp om makt og status i det norske samfunnet der den måten eliten i Den norske turistforening går på tur på, blir selve måten.

Fortolkningen av friluftslivets framvekst som en harmonisk og lineær utviklingsprosess, legger vekt på likhet, identifikasjon og fellesskap som mer betydningsfullt enn forskjeller skapt av klassetilhørighet og livsform. Enhetsmytens sentrale budskap er dermed forestillingen om at det finnes én måte å ferdes $i$ skog og mark på og èn måte å oppleve naturen på som er overordnet de forskjeller i livserfaringer som for 
eksempel alder, kjønn, etnisk tilhørighet, utdanning og bosted skaper. Perspektivet bidrar til å underkommunisere, ikke bare historiske forskjeller, men også at det eksisterer sosiale forskjeller i samtidas friluftsliv. Nylig ble det for eksempel gjennomført en medlemsunders $ø$ kelse i Den norske turistforening som viser at den typiske fjellvandrer er en person med høy utdanning, kommer fra Østlandet og arbeider i offentlig sektor (Østlandsposten 29.7.95)

Et tredje referansepunkt for den nasjonalitetsorienterte forskningen, har vært hvordan utlendinger skildrer og beskriver nordmenns forhold til naturen (for eksempel Archetti 1984, Nedrelid 1993, Long 1993, Witoszek 1991). Sett »utenfra« med »utenlandske $\varnothing$ yne « er det norske turlivet kanskje mer ensartet enn om en ser det »innenfra « og »nedenfra « og tar utgangspunkt i de forskjellige handlinger eller praksiser turlivet består av og de livssammenhenger det inngår i? Det er imidlertid mye som kan tyde på at »slående « ytre likheter, skjuler vesensforskjellige oppfatninger og opplevelser som kan og bør beskrives og analyseres som kulturforskjeller. Med kulturforskjeller mener jeg kvalitativt forskjellige oppfatninger av hva som er det $»$ gode turliv«. Det vil si forskjeller som aldri kan bringes til konsensus uten tap av noe dypt vesentlig i identitet, virkelighetsoppfatning og praksis.

En alternativ tilnærming vil være å ta utgangspunkt $\mathrm{i}$ en humanistisk og fortolkende vitenskapteoretisk posisjon som åpner for at tilværelsen er mangfoldig og sammensatt, og at en og samme hendelse kan tolkes på forskjellige måter som alle kan være »sanne« ut fra gitte forutsetninger (Skirbekk 1985). Et sentralt kulturanalytisk spørsmål er alltid hvem sin kunnskap det er som kommer til uttrykk eller som blir dominerende (Ehn og Löfgren
1982). Som kulturbundet praksis og opplevelsesverden er friluftsliv alltid både situert, relatert, dynamisk; det er uttrykk for noens interesser. En og samme tur kan oppleves forskjellig og bli tillagt vidt forskjellig betydning alt etter hva slags erfaringsbakgrunn og fortolkningsramme den enkelte eller grupper i befolkningen inngår i. Det kommer an på hva slags »kulturell kapital« en har i tursekken, hvor turen starter og hvor den går. Sett fra Finnmark er det flere grunner til å anta at den sterke betoningen av en ensartet norsk turkultur som vi finner både innen forskning og offentlig forvaltning, tilslører betydningsfulle forskjeller. En viktig analytisk utfordring blir å undersøke nærmere hva slags forskjeller det kan være snakk om, samt hvordan og hvorfor forskjeller i friluftsliv skapes, omskapes eller gjenskapes.

\section{Friluftsliv - mellom tradisjon og modernitet}

Det finnes forskere som har vært - og er eksplisitt opptatt av at norsk friluftsliv rommer forskjellige tradisjoner, og dermed er uttrykk for forskjellige kulturelle handlinger. Breivik (1978, 1979, 1986) og Frislid (1983) framhever at det eksisterer regionale og klassemessige forskjeller både i utøvelsen, opplevelsen og oppfatningen av friluftsliv. De kvalitative forskjellene knytter disse forskerne til ulike livsformer: Det norske friluftslivet »står på to bein«, det har en fot i byen og en på landsbygda. Landsbygdas høstingsaktiviteter og turliv er preget av nødvendig virksomhet - av nytte, sjølberging og »attåtnæring «, der grensene mellom arbeid og fritid er flytende. Byens friluftsliv er et overskuddsliv preget av »tur blott til lyst « - av opplevelse og nytelse. Friluftsliv er for byfolk et frirom og en kontrast i forhold til hverdagens 
og arbeidets krav og rutiner, mens turlivet på landsbygda og i primærnæringssamfunn er integrert i hverdagslivet. Breivik (1986) har uttrykt dette blant annet slik:

»Jo meir »abstrakt « og føremålslaust friluftslivet blir, jo meir det blir eit mål i seg sjølv, jo meir ressurssterke og velståande er dei som driv med friluftsliv. Såvel bøndene som arbeidarane hadde jo eit meir jordnært forhold til det heile. Slik er det framleis - det er ikkje desse som har Utsikta eller Toppen som sine absolutte mål. (Breivik 1986:120).«

Det kan derfor synes som et paradoks at også forskere som har framhevet enhet som et vesentlig trekk ved norsk friluftsliv, er opptatt av at friluftsliv samtidig er karakterisert ved mangfold, samt at dette mangfoldet bør ivaretas (for eksempel Faarlund 1971, Nedrelid 1992, Kaltenborn 1993, 1994). Slik jeg tolker det, er det likevel en gjennomgående tendens til at disse forskerne beskriver og analyserer forskjellene mer som »variasjoner over det samme tema" eller som ulike aspekter ved aktiviteter og opplevelser, enn som kulturelle forskjeller. Faarlund knytter for eksempel mangfoldet til bevegelsesglede, tilfredsstillelse ved å mestre vanskeligheter ut fra egen vurdering, naturopplevelse og menneskelig kontakt. Kalternborn er opptatt av at det er store forskjeller både i praksis, opplevelser og motiver, uten å ha et eksplisitt begrep om kulturelle forskjeller i norsk friluftsliv. Når han refererer til kultur er det i betydningen tverrkulturelle (komparative) studier mellom europeiske og nordamerikanske forhold, samtidig som utforsking av friluftslivets mangfold oppfattes som et særlig utfordrende felt for friluftslivsforskningen. Nedrelid er, som jeg tidligere har vært inne på, opptatt av hvordan friluftsliv som nøkkel-symbol i norsk kultur framhever enhetlige trekk til tross for mangfold.
Mangelen på perspektiver, begreper og teorier om kulturforskjeller $\mathrm{i} »$ det norske« er ikke spesielt for forskning om friluftsliv. Sosialantropologer har lenge hevdet at norske forskere generelt har problemer med å se kulturforskjeller i det norske samfunnet. Spesielt har de kritisert etnologene for å være opptatt av å søke etter »det nasjonale«; det vil si etter forenende kulturelle trekk (Hylland Eriksen 1993). En alternativ tilnærming til forståelsen av friluftslivets nøkkel-posisjon i det norske samfunnet kan være å snu problemstillingen og spørre: Hvorfor blir spørsmålet om enhetlige fellestrekk i norsk kultur og friluftsliv et viktig forskningsspørsmål på 1990-tallet? Hvor særegent er det norske friluftslivet sett i forhold til for eksempel de andre nordiske landene, resten av Europa eller NordAmerikansk villmarksliv og »outdoor recreation«? Hvilken betydning har det for vår forståelse og for det praktiske liv, for eksempel for forvaltningen og for pedagoger, om det skulle vise seg at vi her står overfor forskjeller som kan betegnes som kulturelle variasjoner i norske kvinners og menns forhold til fritidsbruk av naturen?

En alternativ fortolkning av friluftslivets stilling som nøkkelsymbol i norsk kultur, kan være at det er det nettopp i kraft av sitt mangfold - og ikke på grunn av enhetlige trekk. I følge Ortner (1973) og Turner (1967) er det slik at samlende nøkkelsymboler har en evne til å forene motstridende synspunkter. Gode nøkkelsymboler er kjennetegnet ved at de er motsetningsfulle og flertydige slik at mange mennesker kan legge sine egne tolkninger inn i dem. Slik sett kan friluftsliv uttrykke både samfunnets enhet og dets indre motsigelser på samme tid. Hylland Eriksen (1993) skriver i en kommentar til 1990-årenes »blomstrende norske nasjonalisme « at oppbyggingen av en samlende nasjonal identitet, er 
påkrevet nettopp i perioder da det ikke lenger er gitt hva norskhet er. I løpet av Friluftslivets år ble det fra offentlige myndigheter gjentatte ganger hevdet at det ikke nødvendigvis lenger er slik at turkulturen går i arv til nye generasjoner. Den må forsvares. En sentral oppgave for Direktotratet for naturforvaltning (1991) inn i år 2000 er derfor å stimulere og tilrettelegge for videreføring av »den norske turkulturen«. Heller ikke i Finnmark der naturen bokstavelig talt er nærværende, er det nødvendigvis slik at kultur- og tradisjoner knyttet til høsting og ferdsel overleveres til nye generasjoner via uformell samhandling gjennom hverdagslige gjøremål. I 1993 arrangerte Statens Utdanningskontor i Finnmark et prosjekt kalt »Vinterunger i Finnmark«. Begrunnelsen var at barn i Finnmark i dag ikke nødvendigvis lærer ferdsel og overlevelse i naturen, eller får et positivt forhold til vinternaturen fordi tradisjonell natur- og uteleik har fått mange konkurrenter; for eksempel fra veksten i innendørsidretter, TV-kanaler, TV-idrett og videospill. Endringer i næringsstruktur har medført at det også i Finnmark er mulig å velge bort aktiviteter i naturen fordi en ikke lenger er avhengig av dem for materiell overlevelse. En underliggende begrunnelse for prosjektet var dessuten å skape en motvekt mot motoriseringen av friluftslivet $^{7}$ - å fremme et friluftsliv der egen kropp er »motor « (Pedersen 1993c).

$\AA$ gjenskape et balansert forhold mellom menneske og natur er vår samtids store utfordring. Von Wright (1994) knytter de grunnleggende problemene til veksttenkningen og til utbytting og kontroll av naturen gjennom vitenskapelig kunnskap og teknologi - til troen på framskritt uten respekt for at det kan finnes grenser for menneskelig virketrang og vitebegjær. Samtidig må vi erkjenne, hevder von Wright, hvor vanskelig det er å løsrive oss fra troen på framskrittet og etablere livsformer med en heldigere balanse mellom menneske og natur. I norsk kontekst er friluftsliv i betydningen »det enkle turlivet «, ofte framhevet som en »vei til alternativ livsformserfaring«. Gjennom friluftsliv er det mulig å etablere en selvrefleksiv og kritisk holdning ikke bare til egen turpraksis, men til det moderne industrisamfunnets forbrukerlivsformer i sin allminnelighet (Næss 1973, Faarlund 1974, Breivik 1978). Å studere friluftsliv utfra teori om modernitetens egendynamikk og som en del av moderne fritidskultur, for slik å fors $\emptyset \mathrm{ke}$ å gripe noen av drivkreftene og de iboende motsetningene vi som enkeltindivider og kollektiver inngår i, er et alternativ til de før omtalte tradisjons- og nasjonalitetsperspektivene. Ved hjelp av et turistisk perspektiv og modernitetsteori viser for eksempel Richardson (1994) hvordan det utstyrsmessig enkle, men fysisk krevende fjellfriluftslivet, uttrykker sentrale modernitetsverdier som erobring og temming av naturen, framskrittsoptimisme, frihet, frigjøring og individualitet - særlig for menn. Å knytte utviklingen av fjell-friluftslivet til turisme, representerer en provoserende kritikk av oppfattelsen av friluftsliv som et kjerne-symbol på norsk identitet. Som »ekte« nordmenn er vi ikke turister på besøk i natur. Naturen er vårt »hjem «. De ulike forståelsesmåtene peker mot iboende motsetninger både i moderne natursyn og $\mathrm{i}$ friluftsliv.

Modernitetsperspektivet representerer en radikalt forskjellig teoretisk tilnærmingsmåte enn tradisjonsperspektivet. Mens den tradisjons- og nasjonalitetsorienterte forskningen vektlegger stabilitet, åpner modernitetsperspektivet for å studere friluftsliv som et dynamisk og relasjonelt fenomen som skapes og omskapes i sam- 
spill mellom samfunnsmessige strukturer og enkeltindividers og gruppers praksiser. Friluftsliv ikke bare speiler samfunnet og kulturen, eller er et resultat av tradisjoner overført fra tidligere generasjoner. Friluftsliv rommer også samfunnsformende og kulturskapende krefter. Friluftsliv i betydningen tur blott til lyst og nytelse, representerer et brudd med før-moderne samfunns nytteforhold til naturen. Det natur(avhengige)livet fiskeren, småbonden og reindriftssamen, og jeg vil legge til deres koner og døtre, har levet - eller lever - er basert på kunnskaper og erfaringer av en helt annen karakter enn det turgåeren, vandreren eller fotturisten har. Det representerer noe »... helt annet skikkelig noe, enn vår moderne turgåing « (Breivik 1979:12). Frykman og Löfgren (1979) hevder med utgangspunkt $\mathrm{i}$ studier av endringer $\mathrm{i}$ det svenske samfunnet at det føres en kultur-

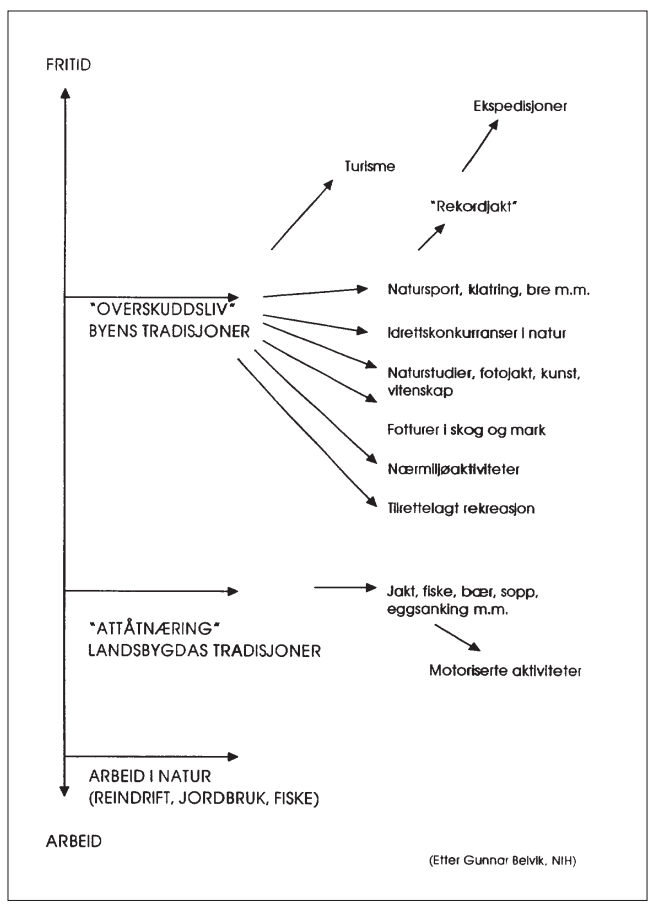

Fig. 2. kamp. Den borgerlige nytelsesorienterte og overskuddspregede (tur)kulturen seirer over bondekulturen ved at bondekulturens oppfatning av naturen som et produksjonslandskap erstattes med industrikulturens forståelse av den »samme « naturen som et fritids- og rekreasjonslandskap ${ }^{8}$. Transformeringen av livsnødvendige virksomheter til »moderne « massefritidsaktiviteter innebærer en kulturell revolusjon der mennesket og samfunnet skapes om. Gjennom framveksten av nye spennende fritidsaktiviteter som idrett, fjellvandringer, sykkelsport og gymnastikk omskaper mennesker sine kropper, rasjonaliserer sine livsformer og lærer seg å være moderne (Ehn, Frykman og Löfgren 1993).

I Finnmark er det mange som i løpet av de siste tiårene har erfart hvordan samfunnsmessige endringer griper dypt inn i den enkeltes identitet, og skaper en situasjon med daglige forhandlinger i ord og handlinger om identitet og tilhørighet. $A$ har prøvd å bli laksefeskar, men a får det ikke tel, sier en mann i 50-årsalderen som er oppvokst med at det bare var å ro ut, slippe snøret ned, og »der satt han «-blodfcersk kokfesk tel midda'n. Han forteller at han verken har tålmodighet eller finner det meningsfullt å stå time etter time i elva for å lure en »laksekonge« på flua. Da er det mye trivligere å småprate rundt et bål og en putrende kaffekjele. På strukturnivå ser vi i samtidas Finnmark hvordan snøscooteren ikke bare har endret folks forhold til naturen, deres oppfatninger av tid og rom. Vi ser hvordan samfunnet omformes og tilpasses snøscooteren; det skapes egne løyper, parkeringsplasser, næringer, organisasjoner, et eget lovverk, en egen forvaltning - så vel som lokale oppfinnelser, nye språklige uttrykk og symboler i form av klær og utstyrsdetaljer. Samtidig er vi vitne til at snøscooteren nettopp symboliserer 
sentrale modernitetsverdier som erobring, framskritt og utvikling, trivsel og velstand, frihet og frigjøring (Pedersen 1993a).

$\AA ̊$ unders $\varnothing$ ke friluftsliv for eksempel sett fra ståstedet til kvinner og menn i utkantNorge - fra grupper som ofte har vært oppfattet som marginale, kan vise seg å være et godt utgangspunkt for nettopp å fange inn kulturforskjeller i samtidas norske turkultur. Det er med et slikt utgangspunkt jeg fortolker en modell utviklet av Breivik (1990) som visualiserer hvordan moderne friluftsliv splittes i stadig nye aktiviteter. Med basis i teorien om at norsk friluftsliv har røtter både i sjølberging og overskuddsliv, etablerer Breivik et åpent, dynamisk og relasjonelt friluftslivsbegrep som tydeliggjør mangfold og variasjon i moderne friluftsliv.

\section{Friluftsliv sett nordfra}

Mange finnmarkinger har vanskelig for å kjenne seg igjen i den dominerende nasjonale, offisielle og vitenskapelige forståelsen av friluftsliv som det å være på vandring uten nytteformål. Selve begrepet friluftsliv oppleves ofte som fremmed og nytt. Mennesker som lever direkte av naturens materielle avkastninger, i Finnmark eller andre steder, opplever ikke naturen først og fremst som en $»$ playground $\ll$. De drar ikke ut på lange turer bare for å slite eller kjenne at det er godt å bruke kroppen, eller for å oppsøke spenning og utfordringer. De drar bare ut når de har et nødvendig ærend å utføre. De landsrepresentative undersøkelsene viser også at det i dag nesten utelukkende er folk i Nord-Norge som plukker bær (Aas og Aasetre 1992). En mannlig lærerstudent, oppvokst i en reindriftsfamilie, kommenterer den $\varnothing$ kende interessen i lokalsamfunnet for det å-gå-påtur-for-turens-egen-skyld slik: »For mae betyr vidda arbei'. AE går ikke ut for å smile tel sola.« En tidligere yrkesfisker, som på grunn av fiskerikrisa i Barentshavet begynner på lærerstudiet i 35-årsalderen, »smaker« på begrepet friluftsliv før han sier: »Vi bruker ikke det ordet. For ma e det et fag på Høgskolen. « En kvinne i 45-årsalderen sier det slik: »E har egentlig aldri setta navn på det om a ska vare helt arlig. A har aldri setta navn på det at a har dreve friluftsliv. Det har liksom bare vart en naturlig ting.«

Den lokalt forankrede og høstingsbaserte naturbruk kan videre illustreres med følgende eksempel: I begynnelsen av august 1990 opplevde Finnmark den beste moltehøsten i »manns minne«. I »hele fylket« bugnet de enorme myrområdene av gyldne bær, og folk gikk »mann av huse « $\mathrm{i} » j$ jakten på viddas gull $\ll$. Folk forteller at de uten særlige anstrengelser plukket 50-100 kg molter på et lite myrområde i løpet av en helg. I den forbindelse gir redaktøren i Finnmarks største avis - Finnmark Dagblad (4.8.1990) - følgende skildring av det »finnmarkske« turlivet:

»Det å høste av naturen er en livsstil i Finnmark. Naturen betyr kanskje mer for finnmarkingene enn vi er villig til å innrømme. Vårt frie liv i Finnmark er egentlig sterkt regulert av tidsbestemte aktiviteter i naturen. Om sommeren er det livet ved havet og elva i jakten på seien og laksen som binder oss opp. Så er det bæra, og deretter ørreten, rypa og snescooteren. I oktober, november og desember er vi sammen om å fortære bæra, røykalaksen, rypa og fenalåret etter først å ha vært i felles badstu. Det er som et evigvarende rituale bestemt av naturens gang.«

Denne fortettede beskrivelsen vil mange finnmarkinger kjenne seg igjen i. Hverdagslivet i 1990-årenes Finnmark har en syklisk inndeling sterkt preget av en tidsorganisering som kjennetegner tradisjonelle eller før-moderne samfunn (jfr Ehn og Löfgren 1979). I det praktiske liv er imid- 
lertid ikke bildet like entydig. Beskrivelsen kan derfor tolkes både som en hyldest til lokal natur og kultur, og som et håp om å holde fast livsformer og en frihetsfølelse som engang var, og som en ønsker skal fortsette inn i evigheten...

Finnmark har i flere hundre år vært preget av både samisk, norsk og kvensk (finsk) kultur; mens de rike naturressursene - fisken i havet, mineralene i fjellene, reindrift og høsting av vilt, fisk og bær på viddene - har dannet det materielle livsgrunnlaget. Brenningen av Finnmark under siste del av annen verdenskrig og gjennoppbyggingen etterpå, førte til en rivende moderniseringsprosess. I løpet av de siste tretti årene har primærnæringene »mistet « hegemoniet som dominerende næringstilpasninger, mens nye yrkesgruppersærlig innen privat og offentlig tjenesteyting - har vokst fram. Skiftet i næringsstruktur kombinert med $\varnothing$ kende utdanningsnivå, innebærer samtidig en overgang fra hovedvekt på uformell og erfaringsbasert opplæring til kunnskapsformidling som bygger på formell opplæring, forskningsbasert og teoretisk kunnskap. En annen konsekvens av disse strukturendringene er at det moderne samfunnets skille mellom arbeid og fritid, natur og hverdagsliv er blitt skarpere. Dette gjelder ikke bare for lønnstakeren, men også fiskere, bønder og reindriftsutøvere skiller idag mellom arbeid og fritid. Slike endringer kan imidlertid innebære et tap av uformell og erfaringsbasert kunnskap om lokale forhold. Spesielt kan en tenke seg at dette får konsekvenser for tilegnelsen av naturkunnskaper og av kunnskaper om ferdsel, overlevelse og høsting i naturen. Når slik kunnskap ikke lenger nødvendigvis tilegnes gjennom arbeid og dagligliv, får fritidsbruk av naturen og formell opplæring $\varnothing \mathrm{kt}$ betydning. I skolen gjenspeiler dette seg ved at friluftsliv - ferdsel, opphold og høsting i naturen - er blitt både skolefag, studiefag og forskningstema. Bedrede kommunikasjoner, utviklingen av informasjonsteknologi, ut- og innflytting, feriereiser og turisme har dessuten resultert i omfattende kontakt med omverdenen. Reiseliv og turisme har det siste tiåret vært den største vekstnæringa, og er den virksomhet mange setter sitt håp til når velferden og sysselsettinga for framtida skal sikres. Idag er det like mange som arbeider innen reiseliv og turisme som det er fiskere i Nord-Norge (Tjelmeland 1994). Dyptgripende samfunnsmessige strukturendringer er ikke bare en realitet som folk flest må forholde seg til. Omstilling er 1990-årenes sentrale politiske slagord.

Grovt skissert er det mulig å identifisere tre hovedformer for tur- og friluftsliv i 1990-årenes Finnmark: høsterne, vandrerne og spesialistene. De tre gruppene må betraktes som idealtypiske og analytiske kategorier som i det praktiske liv kan være vanskelig å skille 9 . Høsterne ut $ø$ ver et mangesidig og sesongbetont turliv basert på bærsanking, jakt, forskjellige former for fiske, vedhogst mm. Denne formen for turliv har sin opprinnelse i naturnære livsformer der høsting var en nødvendig og selvfølgelig del av familienes husholds $\varnothing$ konomi. Naturen er alltid nær, og en drar bare ut når en har et bestemt ærend å utføre, og ikke fordi det er fridag. Helt opp til vår samtid har høsting til eget forbruk vært den dominerende form for ferdsel og opphold $\mathrm{i}$ naturen både blant samer, kvener og nordmenn - selv om det nok har eksistert og eksisterer forskjeller mellom gruppene. I det tradisjonelle »høstingslivet « eksisterer det en tydelig og selvfølgelig arbeidsdeling mellom kvinner og menn både før, under og etter tur. Samtidig har kvinnenes ansvar 
for barn og hus begrenset deres ferdsel. Denne formen for turliv er i hovedsak lokal; den er basert på detaljerte kunnskaper om lokale forhold og foregår på en selvorgansiert måte der enkelte familier tradisjonelt har hatt hevd på avgrensede områder (Gaski 1993). Dette, som jeg vil kalle et arbeidsintensivt turliv, beskriver en kvinne i slutten av 50-årene slik: »Vi e' så aktiv' at a vet ikke ka ti' vi fär ti' tel alt«. Kunnskap og ferdigheter er blitt overført direkte fra mor til datter, fra far til sønn, gjennom arbeidsoppgaver som er integrert $\mathrm{i}$ hverdagslivet. Mens jentene ble oppdratt til husholdsarbeid, var guttenes oppdragelse knyttet til arbeidet ute. Tradisjonelt har en verken hatt spesielle turklær eller spesielt turutstyr. Siden turen mer oppfattes som en transportetappe og et middel til å nå det egentlige målet - å høste, har det vært både legitimt og ønskelig å redusere anstrengelsene for å gjøre innhøstingen mer tilgjengelig og mindre fysisk krevende. En har derfor vært snar med å ta i bruk forskjellige former for teknologi; traktor, snøscooter, »firhjulinger«, småfly og motoriserte isborr. Både oppfinnsomheten og sjølbergingsevnen er stor. Hjemmeprodusert utstyr kombineres ofte med moderne teknologi, og tilpasses lokale forhold og individuelle behov. Da det ikke lenger er nødvendig å høste for livsoppholdet for »folk flest «, er denne form for turliv, samt de kunnskaper og ferdigheter som er knyttet til den, mange steder i ferd med å bli mindre markert blant yngre generasjoner. Gaski (1993) beskriver hvordan høsting særlig inngår som en selvfølgelig del av den samiske befolkningens hverdagsliv, samt hvor tett sammenvevet samisk identitet er med det lokale brukslandskapet. En lokalpolitiker har uttrykt dette slik: »Utmarka er en del av befolkningens levestandard «. I denne sammenhengen vil det føre altfor vidt å drøfte forholdet mellom de etniske gruppene og deres bruk av naturen. Poenget her er å sannsynliggjøre at naturopplevelser og friluftsliv oppfattes anderledes i Finnmark enn det som framstilles som en enhetlig norsk friluftslivsideologi.

For vandrerne oppfattes turen, naturopplevelsen og det »gode slitet « som et mål i seg selv. Gjennom enkelt utstyr søker vandrerne nærkontakt med naturen. Denne formen for friluftsliv skiller seg blant annet fra det høstingsorienterte turlivet ved mer regelmessighet, samt ved idealene om å gå ut på tur året rundt og i all slags vær. En skiller ikke like skarpt mellom sesongene for jakt, seifiske, bærplukking $\mathrm{mm}$, selv om også denne formen for turliv i Finmark blir preget av de markerte årstidene. Derimot er den enkeltes fritid avgjørende. Fritid betyr imidlertid oftest noe annet for kvinner enn for menn, og undersøkelser viser at kvinner utøver mindre friluftsliv enn menn. De deltar på færre og kortere turer, og går oftere på tur i nærmiljøet og sammen med familien (Hage red. 1988, Pedersen 1992, 1994). Dessuten, opplæring til friluftsliv oppfattes som en viktig del av barneoppdragelsen. Lokalt er forholdet til denne »nasjonale« formen for friluftsliv preget av en oppfatning om at dette er noe som er kommet utenfra og inn i den lokale kulturen med »søringan« - med leger, prester, lærere og embetsmenn. Denne formen for friluftsliv har heller aldri helt fått gjennomslag blant de brede lag av befolkningen i Finnmark. Dette kommer for eksempel til uttrykk ved den oppslutning - eller mangel på sådan, som Den norske turistforening har. De to lokalforeningene i Finnmark; i Sør-Varanger og i Alta har tilsammen 307 medlemmer, noe som bare utgjør omlag 0,4 prosent av befolkningen ${ }^{10}$. De lange og fysisk krevende turene, med en- 
kelt utstyr er dominert av innflyttere og (lokale) menn som i sin ungdom har vært aktive i utholdenhetsidretter; for eksempel ski eller friidrett.

Spesialistene utgjør en heterogen gruppe som dyrker en eller flere aktiviteter som krever store investeringer $\varnothing$ konomisk, tidsog/eller kunnskaps- og ferdighetsmessig; for eksempel fluefiskere etter laks ${ }^{11}$, rypejegere med hund ${ }^{12}$, snøscooterbrukere, nomekjørere med polarhunder, havpadlere og »ekstreme villmarkinger ${ }^{13}$. For å kunne delta i disse aktivitetene kreves det så stor personlig innsats av den enkelte at det preger ens livstilpasning. Det jaktes og fiskes ikke lenger for livsoppholdet, men for sportens - spenningenes, utfordringenes og rekreasjonens skyld. En kan heller ikke se bort fra at en viktig drivkraft er jakt og fiske etter personlig prestisje og status. De forskjellige gruppene er ofte lett synlige i lokalsamfunnet og lar seg identifisere så vel gjennom sine handlinger som ved hjelp av utstyr og klær. Et vanlig innslag i bygdesamfunnet om vinteren er store biler og tilhengere med snøscootere, hunder og sleder. Aktivitetene egner seg godt for å markere distinkte identiteter og livsstiler som atskiller seg fra en mer udefinerbar og usynlig »masse« av turgåere og høstere. Felles for disse aktivitetsformene er avhengighet av og tilknytning til avansert teknologi, kommersialisering, mediefokusering og »turistifisering«. Dessuten synes det å være slik at dess mer spesialiserte, kostnadskrevende, teknologiavhengige aktivitetene blir, dess mer som kreves av personlig innsats og investering, dess mer mannsdominerte blir de. Det finnes kun èn jentedominert gruppe som kan kategoriseres inn under den heterogene gruppa av »spesialister «; de mange unge jentene med interesse for hest og turridning. Mens høsterne er generalister med allsidig kunnskap om lo- kale forhold, ser vi her tendenser til spesialisering og konsentrasjon av interesse og ferdighetstrening til en eller noen få aktiviteter. Både jakthunden og polarhundene må trenes hele året, mens laksefisket forberedes gjennom vintermånedene ved binding av fluer, utvikling av utstyr og utveksling av informasjon. Det legges ofte mer vekt på tekniske ferdigheter enn på utholdenhet og styrke. Interessen for disse formene for turliv er $\varnothing$ kende, samtidig som deltakerne har forskjellig sosial og kulturell bakgrunn. De senere årene deltar kvinner både enkeltvis og i grupper i økende grad på flere av de nevnte områdene. Dessuten har enkeltkvinner lokalt tatt initiativ for å gi spesielt tilrettelagte opplæringstilbud til kvinner, for eksempel innen jakt, (lakse)fiske og hundekjøring (Pedersen 1993b). Samtidig er hundekjøring, laks, ryper og snøscooter viktige »ingredienser« i markedsføringen av Finnmark som turistmål. Urry (1987) tolker fritid og turisme som et statusgivende prosjekt. Hva slags aktiviteter folk engasjerer seg $\mathrm{i}$, forteller hvor i samfunnshierarkiet de beveger seg sosialt sett. Han hevder at det er den framvoksende tjenesteytende klassen som gjennom lekfulle, selvrealiserende og selvutfoldende fritidsaktiviteter søker å etablere, uttrykke og bekrefte distinkte identiteter. Framveksten av mangfoldige lokale friluftslivsstiler inngår med andre ord i et globalt mønster, samtidig som de samme aktivitetene bidrar til å integrere den lokale kulturen i et globalt forbruksmønster. Globaliserende og individualiserende tendenser impliserer likevel ikke at den enkelte nødvendigvis definerer seg ut fra klassetilhørighet, etnisitet o.1., men snarere at den enkelte fors $\varnothing \mathrm{ker}$ å skape tilværelsen og seg selv gjennom bestemte livstilsformende aktiviteter i naturen. Nærmere analyser vil imidlertid vise at det eksisterer sosiale for- 
skjeller både innenfor og mellom de gruppene som her er samlet under kategorien spesialister.

Til dels »lever« de forskjellige formene for turliv ved siden av hverandre. I skjæringspunktene - i kulturmøtene - skjer det daglige forhandlinger der den enkeltes identitet og status, og ulike natur- og turforståelser settes under debatt. Hva som blir betraktet som framskritt og utvikling, positivt og negativt, nytt og gammelt, lokalt og fremmed, er verdispørsmål. Svarene som gis er avhengig av » $\varnothing$ ynene som ser « - det ståsted, den erfaringsbakgrunn og kontekst aktivitetene fortolkes inn i. Slik oppstår det kraftfulle lokale omformingsprosesser samtidig som det utkjempes kamper mellom ulike virkelighetsoppfatninger, og om hvem som har rett til å uttale seg og bestemme over hvordan Finnmarksnaturen bør forvaltes. Spesielt er dette de siste 10-15 årene kommet til uttrykk gjennom kampen om »snøscooteren «; en konflikt som kan tolkes som et nøkkelsymbol for grunnleggende motsetninger i Finnmarkskulturen (Pedersen 1993a). I den sterkt emosjonelle debatten er det motsetningsforholdet mellom en nasjonal og en lokal naturforståelse og -bruk, ofte uttrykt som en polarisert konflikt mellom ski og »scooter «, »sør« og »nord «, mellom »innflytter« og »lokalbefolkning«, som er kommet i fokus. Lokalt blir det hevdet at $»$ Snøscooteren er selve meningen med livet« og en selvfølgelig del av friluftslivet. Offisielt defineres ikke snøscooteren inn under friluftslivsbegrepet, men betraktes og forvaltes som naturinngrep. Mens snøscooterkonflikten nesten daglig er å finne i den offentlige debatten, finnes det også andre, mindre åpent debatterte områder der viktige motsetninger i forståelsen av friluftsliv kommer til uttrykk, for eksempel gjennom synet på tilrettelegging for fri- luftsliv. Tradisjonelt har folk ferdes på stier og i områder der de er godt kjent og har hatt lokale kjennemerker. Den norske turistforenings T-merking og annen skilting av løyper slik en kan se det i sentrale fjellstrøk og i turområdene rundt de store byene i Sør-Norge, blir ofte framhevet som både fremmed, stygt og unødvendig: »Men det e’ kanskje nåkka søringan traeng «? De siste årene har vi imidlertid sett $\varnothing \mathrm{kt}$ innsats fra lokale myndigheter nettopp med løypemerking. Det er kanskje slik at også andre grupper enn tilflyttere har behov for $\varnothing \mathrm{kt}$ tilrettelegging både sommer og kanskje særlig om vinteren for å oppleve trygghet på tur.

Samtidig er et annet latent og dyptgripende spenningsforhold; det mellom samisk og norsk, i ferd med å bli mer artikulert. Dette tydeliggjøres gjennom en debatt om det samiske folks rettigheter til land og vann i Finnmark (Norges offentlige utredninger 1993, 1994). Denne debatten aktualiserer både forholdet mellom etniske grupper internt $\mathrm{i}$ regionen, og forholdet mellom det samiske samfunn og den norske nasjonalstaten ${ }^{14}$. Dette er en debatt som lenge har vært i emning, og som sannsynligvis vil prege kultur og samfunnsliv i Finnmark inn i neste årtusen. Skal forvaltningen av hele eller deler av Finnmarksnaturen og retten til å høste av naturressursene i framtida skje på etnisk grunnlag? Men hvem er same og hvem er norsk? I det flerkulturelle Finnmark, med $\varnothing \mathrm{kt}$ mobilitet og blandingsekteskap, er heller ikke det entydige kategorier. Samtidig har vi de siste to tiårene sett endringer i retning av en stigende samisk nasjonal selvfølelse og byggingen av moderne samiske institusjoner (Høgmo 1995).

De utviklingstrekk ved turlivet og folks bruk og opplevelser av naturen i Finnmark som jeg her har gitt et omriss av, kan opp- 


\section{Snøscooterne klargjøres}

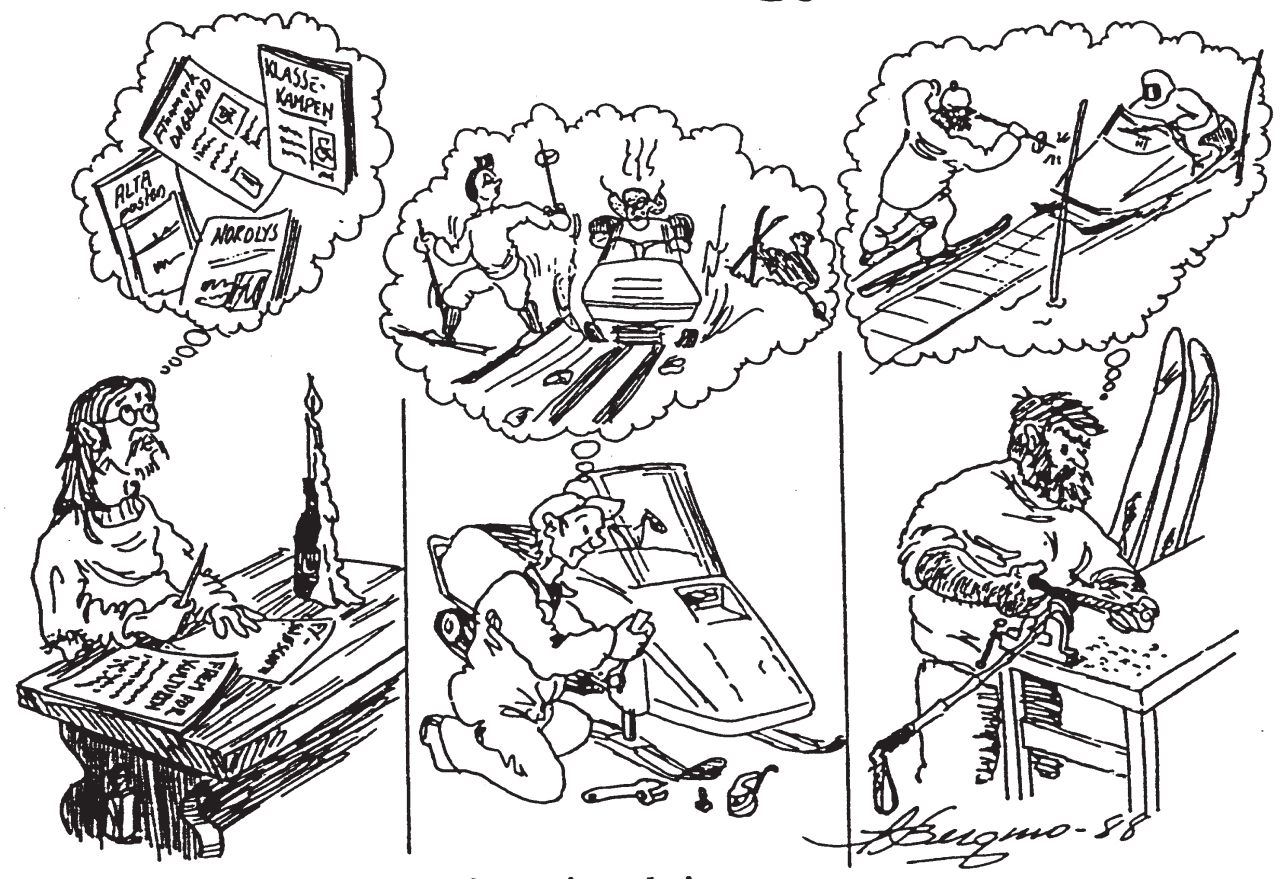

- Mả ha utstyret i orden før «vinterkrigen»

Fig. 3.

summeres ved å si at naturens rolle som livgivende materiell ressurs, er erstattet av en situasjonen der forholdet til naturen er blitt mer symbolsk betydningsfull; som identitetsmarkør og opplevelsesarena. Samtidig ser vi mange eksempler på at nettopp i forholdet til natur og friluftsliv er det flere interesser som kommer i konflikt - et bruksorientert og estetisk syn på naturen, et teknologioptimistisk og et teknologikritisk syn, et turistoptimistisk og et turistkritisk syn, en samisk og en norsk oppfatning av bruksrettigheter og eiendomsforhold, samt en lokal og en nasjonal oppfatning om hva friluftsliv bør være.
Natur og turliv - ramme for kulturell mobilisering

Frykman og Löfgren (1979) hevder at den seine industrialiseringen og urbaniseringen gjør at svensker og den svenske kulturen står nærmere naturen og »livet på landet« enn hva tilfellet er i mange andre land i vesten. Den polske kulturforsker Nina Witoszek (1991) hevder på bakgrunn av studier av den nære samhørigheten med naturen som preger den norske kulturen, at nordmenn er Europas siste naturstamme. I Finnmark med »uendelige « vidder, lav befolkningstetthet og med moderniseringpro- 
sesser som sentralisering, urbanisering og industrialisering som relativt ferske erfaringer, skulle en tro at folk har enda mer naturkontakt og føler enda sterkere samhørighet med naturen enn både europeere, svensker og nordmenn flest. Med utgangspunkt i den dominerende forståelsen av friluftsliv som jeg skisserte innledningsvis, kan en spørre om det er slik at finnmarkinger først og fremst drar på tur for å bekrefte eller få bekreftet sin nasjonale identitet? Er vektleggingen av høstingstradisjoner kun et uttrykk for at Finnmark ennå »henger« etter i den nasjonale utviklingen? Er det slik at folk i Finnmark er i ferd med å »ta over« og lære »det nasjonale « friluftslivet? Er det kun et spørsmål om tid før »hele« befolkningen i Finnmark »parkerer snøscooterne« og begynner å »gå-på-turfor-turens-egen-skyld « - og ikke fordi de har praktiske ærend å utføre eller noe å høste?

Svarene på slike spørsmål er nei. I 1990årenes Finnmark er mange opptatt av å definere og markere en særegen lokal eller regional identitet i tilknytning til naturen. Forholdet til naturen beskrives ofte kroppslig; folk sier at de »må ut«, de føler »en hug og et sug etter å dra ut«, eller »det krible i fingran «. Og folk drar ofte til områder der de er godt kjent, til områder som for dem er fortettet med mening; med minner og opplevelser som gir følelse av tilhørighet og kontinuitet i en omskiftelig verden. Tilflytteren har det som regel anderledes. Han eller hun må enten spørre seg fram, eller lære den lokale naturen å kjenne på egenhånd. Det finnes mange eksempler på at tilflyttere med et solid kulturelt fundament $\mathrm{i}$ det nasjonale vandrerfriluftslivet investerer både tid, penger og krefter på å tilegne seg kompetanse i lokale høstingstradisjoner. Den som er født og oppvokst i Finnmark kan imidlertid ha et ambivalent forhold til lokal natur og kultur. Naturressursene i nord representerer rikdommer som ikke har latt seg høste uten lidelse. Hverdagslivet har vært en stadig kamp for å overvinne naturen, uværet, mørket, kulda og fortvilelsen. Forsiktig antyder enkelte at det er noe fattigslig over det å høste, særlig dersom en er avhengig av det for livsoppholdet. Nord-Norge, og i særdeleshet Finnmark, har helt opp til vår samtid blitt betraktet som en underutviklet landsdel både økonomisk, næringsmessig og kulturelt, samtidig som både statens og kirkens representanter har sett det som en viktig oppgave å oppdra »de ville« i nord til å bli siviliserte og gode nordmenn. Et resultat er at forholdet til sentrum, til $s \phi r$ og til de som sitter med overtaket, er et gammelt nordnorsk traume. Èn folkelig reaksjon har vært trassig og vedvarende motstand mot integrasjons-bestrebelsene, samtidig som det har festet seg en følelse av at framtidsmulighetene ikke ligger i »heimbygda«. De senere årene har vi sett at til tross for, eller kanskje nettopp på grunn av at hverdagslivet mottar sterke impulser både fra det nasjonale fellesskapet og fra verdenssamfunnet, er det en $\varnothing$ kende bevissthet blant folk om at de har noe verdifullt felles. Det er skapt et grunnlag for en moderne nordnorsk regionalisme (Drivenes m.fl. 1994).

I Finnmark har det de siste årene skjedd en kulturell mobilisering der bevisstheten om de verdifulle ressursene som Finnmarksnaturen rommer, har $\varnothing \mathrm{kt}$. I Alta er for eksempel »det eventyrlige« laksefisket i Altaelva en spesielt viktig arena for markering av lokal kulturell kompetanse og identitet $^{15}$. For en stor del av Finnmarks befolkning har snøscooteren - de mulighetene og det sosiale samværet den skaper, blitt det samlende »sentrum《 som gir »livet innhold og mening« (Pedersen 1993a). For 


\section{Ang. levekår i Finnmark}

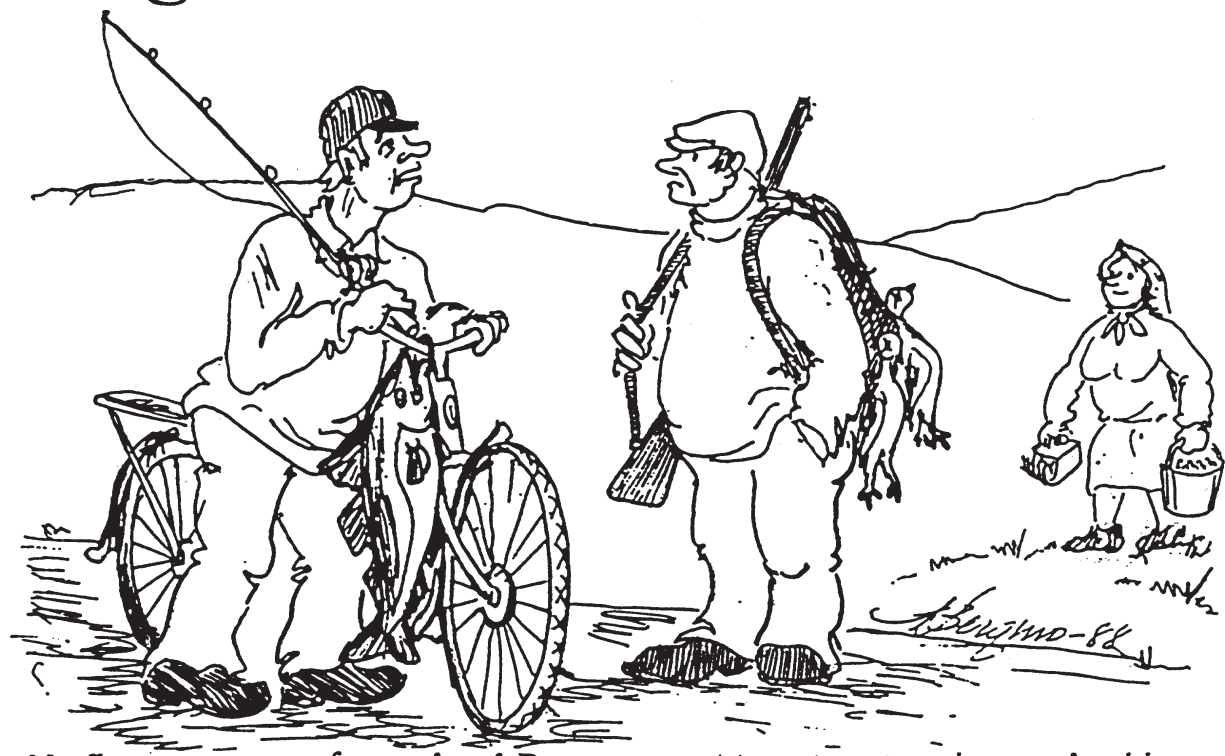

No flytte ce sø̄rover, for ce säg pá Dagsrevyen at tomatän og ceplan va sä søkkanes billig i Oslo.

Fig. 4.

andre inngår både laksefiske, snøscooterkjøring, rype-jakt og moltebærplukking i identitetsmarkeringen. Dette er relativt lett tilgjengelige ressurser som dels er forbeholdt lokalbefolkningen ${ }^{16}$. Kort sagt: Dette er noe befolkningen i Finnmark har - og som folk utenfor fylket i økende grad er villige til å betale relativt dyrt for å få del i! Bildet er ikke spesielt for Finnmark. Andre steder i Nord-Norge er det kystkulturen og restaureringen av gamle bruksbåter som danner grunnlag for lokal kulturell mobilisering (Kramvig 1995).

Kramvig fortolker mobiliseringen rundt kystkulturen som del av en motstandskamp mot generelle moderniseringsprossesser i det norske samfunnet. Gjennom mobilisering av tradisjon kan folk opponere mot det fragmenterte fellesskapet som det moderne samfunnet »tilbyr«, og som gir framtid og modernisering forrang framfor fortid og tradisjoner ${ }^{17}$. Det paradoksale er, sier Kramvig, at det ikke er fortida som aktiviseres på denne måten. Det er ikke båten som framkomstmiddel som her kommer i fokus, men den symbolske kommunikasjonen av identitet, fellesskap og historieforståelse. I 1990-årenes Finnmark er det ikke snøscooteren som transportmiddel eller laksen og moltene som næring og mat som »står på spill«, men den symbolske mening som uttrykkes og kommuniseres gjennom disse aktivitetene. Selv om folk gjør det samme som før, har aktivitetene fått et nytt innhold og inngår i andre kontekster enn før: »Det e' ikke matauke det herran her, « sier folk, og tar likevel fiskestanga med på tur. Deltakelse i fisket etter laks i Altaelva i 
juni måned fram til St.Hansaften, da det er åpent og gratis for lokalbefolkningen, kan ha mange motiver. For noen er det mulighetene til å få laks - f $\phi r$ det koster penger og er begrenset adgang, som er viktig. For andre er det jakten på spenning, utfordring og temming av vill-laksen, samt egen ære som står på spill. I de tre ukene »gratisfisket« varer kan nederste del av Altaelva sammenlignes med Storgata i en småby. Det er dit folk går for å se og bli sett, og for å høre nytt. Kaffebålene er mange og nettene lange »in the land of the midnight sun «. Da er fiskeren både omgitt av journalister og et kompetent publikum. Da handler det mindre om naturopplevelse, stillhet og refleksjon - eller matauke, og mest om å være - eller om å bli akseptert som - deltaker i »den lokale kulturen«. Det handler om å representere seg selv og lokalsamfunnet og om å være der det som er betydningsfullt skjer.

Et fellestrekk ved flere av de utforminger turlivet får lokalt, er at de utfordrer den etablerte nasjonale og offisielle forståelsen av hva friluftsliv er og bør være. Gjennom vektlegging av lokal kunnskap og lokale tradisjoner, eller noe som oppfattes som lokal kultur ${ }^{18}$, mobiliserer mange kvinner og menn i Finnmark motstand mot den nasjonale, hegemoniske og endimensjonale forståelsen av friluftsliv som »det å være på vandring «. Det trenger imidlertid ikke å bety at de samtidig motsetter seg modernisering. Snarere tvert imot. For mange er det viktig nettopp å være moderne. Begrepene kulturell identitet og kulturell mobilisering brukes i denne sammenhengen som samlebegrep for de kontinuerlige prosesser både enkeltindivider og grupper gjennomlever for å bearbeide endringer og motsetninger i tilværelsen, for slik å skape mening med livet. Modernisering medfører stadige oppbrudd i forhold til tradisjoner, og gir både kvinner og menn økt valgfrihet og handlingsrom, samtidig som kravene til den enkeltes målrettethet og bevissthet er blitt større (Rudie 1984). Det skapes en ny form for kompleksitet med et nytt forhold mellom enkeltindividet og omgivelsene; individet speiler det internasjonale, i tillegg til eller i stedet for det lokale. Dette er en utvikling som er ledd i en overordnet og global kulturhistorisk prosess; utviklingen fra tradisjonelle, smådimensjonerte samfunn til moderne, komplekse og globalt integrerte samfunn. Turlivet skapes - leves og oppleves - i en kompleks sosiokulturell kontekst der elementer både fra tradisjonell »nytte- bruk« av naturen, en estetiserende og nytende naturromantisk holdning og det aller siste i teknologi, inngår. Å rette søkelyset mot fortida og tradisjonelle aktiviteter i naturen er altså en måte å møte utfordringene $\mathrm{i}$ det sen-moderne samfunnet på. Å vise »verden« at Finnmark er en moderne landsdel som er innlemmet i det norske velstandssamfunnet ved å kjøre i stor hastighet over fjellviddene på en snøscooter utstyrt med det aller siste innen »hightech« navigasjonsutstyr, er en annen. Noen ganger er det viktig å være lokal og tradisjonsorientert. I andre situasjoner er det »verdensborgeren « som blir eksponert. Gjennom tur- og friluftsliv er det mulig å forhandle om og forvalte sin identitet slik at en samtidig er tradisjonell og lokal, »super moderne « og global (Pedersen og Viken under publisering). Det handler om å være lokal på en moderne og global måte. Denne »mixingen « tydeliggjør hvordan det er umulig å fastslå hva som er tradisjonelt, »ekte« og lokalt - og hva som er moderne, importert og nytt. Et godt eksempel på dette er den raske integreringen av snøscooteren. Idag, tretti år etter at den første gang ble introdusert i den samiske kulturen som hjelp i reindrifta, oppfattes den av mange 
som en uunnværlig del av lokal kultur og turliv. Forsøkene på å vedlikeholde, skape eller gjenskape en særegen lokal turkultur og identitet, bestemmes altså ikke bare av tradisjon, men av hva som gir muligheter for personlig identifikasjon og selvutfoldelse - av hva som vinner aksept som »lokal tradisjon «.

Menneskers selvoppfatning er relasjonell og situert, og skapes og gjenskapes gjennom handling og refleksjon som inngår i en rumlig og tidsmessig kontekst. Under sen-moderniteten er vilkårene for identitetsdanningen endret; tradisjonen, religionen, familien, nasjonen og lokalsamfunnets betydning er anderledes enn før, mens ens egen kropp og naturen blir særlig utsatt og opplevelsesrelevant - en slags nøkkel-kategorier for identitetsdanningen. Jeg har tidligere vært inne på hvordan ski og friluftsliv, samt polferdene i 1880-90årene ble benyttet $\mathrm{i}$ den politiske kampen for å definere og markere det norske folk som et selvstendig folk - anderledes enn svensker og dansker. I 1990-årenes Finnmark markerer den lokale selvhevdelsen gjennom laks, snøscooter, ryper eller molter en dobbelthet: Folk i »utkanten« har særegne tradisjoner og en verdifull kultur å ta vare på - som er unik og anderledes enn det som ofte oppleves som felles nasjonal kultur - definert fra »sør«, samtidig som de er på høyde med resten av den vestlige verden materielt og teknologisk sett. Dessuten - når natur og friluftsliv brukes som materiale for å definere nasjonal eller lokal kultur, er det med referanse til aktiviteter og arenaer dominert av menn.

\section{Friluftsliv - en arena for maskulin identitetsmarkering}

Kunnskap om de beste fiskevannene og jaktområdene, samt ferdigheter i å ferdes i naturen er kompetanse mange menn som er født og oppvokst i Finnmark er i besittelse av. Slik kompetanse blir ofte særlig relevant i samhandlingen med menn fra »sør«, som ofte har (eller har hatt) mer teoretisk skolering og/eller innehar viktige posisjoner i foreninger og offentlige institusjoner. »Praktikerne « hevder at de kjenner de lokale forholdene best. Fordi de har ferdes mye ute over mange år, vet de også hvor ressursene finnes, samt hvordan de bør forvaltes. I tillegg til det praktiske og faktiske innholdet i disse forhandlingene, kan en fortolkning være at det her foregår en kamp mellom menn om makt og innflytelse, status og prestisje i lokalsamfunnene. Den sentrale betydningen jakt, fiske og snøscooterkjøring som fritidsaktiviteter idag har for å markere og bekrefte en verdig, »tradisjonell« og lokal mannlig identitet, må sees på bakgrunn av at de mannsdominerte yrkene knyttet til primærnæringene i løpet av de siste tyve årene har mistet sin funksjon som arenaer for utforming av en selvfølgelig og udiskutabel mannlig identitet. Disse aktivitetene framstår i et slikt perspektiv som arenaer for videreføring og gjenskaping av lokal mannlig identitet basert på praktiske ferdigheter og naturkunnskaper, på beherskelse av de lokale omgivelsene. Både den oppmerksomhet lokale media gir menn på jakt, som fisker laks eller kjører snøscooter, og mannsdominansen og det emosjonelle engasjementet som preger de mange debatter om forvaltningen av Finnmarksnaturen som føres i kommunestyrer, ring-inn-programmer på lokal radio, i hverdagslige samtaler og i leserinnlegg i aviser, bidrar til å styrke friluftsliv som et maskulint prosjekt. Samtidig kan vi ikke se bort fra at friluftsliv som idrett (jfr Bonde 1991) representerer betydningsfulle arenaer hvor menn med »ikke-praktiske« yrker kan dyrke sentrale 
manndomsidealer som høy moral, selvkontroll, beherskelse av »villmarka«, utholdenhet, mot og styrke. Hva slags prosesser som igangsettes når kvinner i større antall beveger seg inn på friluftslivsarenaer som tidligere nesten utelukkende har vært forbeholdt menn, har vi idag bare begrensede kunnskaper om.

Jeg har andre steder mer inngående drøftet kvinners forhold til friluftsliv (Pedersen 1992, 1993b, 1994). Her nøyer jeg med å skissere et analytisk perspektiv og problemstillinger som kan kaste lys over utforskingen av kjønnsforskjellene i turog friluftsliv. I det bildet av mangfoldig differensiering i friluftsliv jeg har skissert, er det ikke mulig å identifisere et klart grensesnitt mellom kvinners og menns friluftsliv selv om menns dominans er motstandsdyktig overfor forandringer. Kjønnsforskjeller i friluftsliv lar seg likevel ikke fange inn i en enkel todeling - som biologisk kjønnsdikotomi. I stedet gir det mer mening å snakke om utforming av kvalitativt forskjellige kvinneligheter og mannligheter i friluftsliv - som i idrett (Messner 1990, Hargreaves 1994) og i samfunnet generelt (Moore 1988). Relasjonene mellom kvinner og menn i friluftsliv inngår i et sammensatt mønster der både livsform, alder, utdanning, etnisk og regional tilhøringhet spiller inn og skaper forskjeller både $\mathrm{i}$ deltakelsesvilkår og fortolkningsrammer. Til tross for - eller kanskje nettopp på grunn av, den sterke mannsdominansen i friluftsliv, er det bare sjelden at menns og kvinners forhold til tur- og friluftsliv blir åpent diskutert eller forhandlet om. En kulturanalytisk og feministisk fortolkning kan være at vi i friluftsliv befinner oss i et felt av kulturen der vi ikke er istand til å reflektere over våre kjønnskulturelle forutsetninger. Kjønnsrelevans i friluftsliv er et område for det ikke-diskuterbare, det selvinnlysende, det vi alle tar for »gitt «. Det framstår som »natur « for oss, og blir også ofte fortolket som biologisk betingede forskjeller. Heller ikke friluftslivsforskningen eller forvaltningen har interessert seg for kjønnsforskjeller i friluftsliv, som slik sett må sies å tilhøre både det regionale turlivets, den nasjonale turkulturens og forskersamfunnets »tause « kunnskaper. En konsekvens av at kjønnsrelevans ikke debatteres verken $\mathrm{i}$ hverdagslivet eller $\mathrm{i}$ forskningen, er at menns turerfaringer universialiseres og presenteres som fellesmenneskelige erfaringer. $\AA$ unders $\varnothing$ ke betydningen av kjønnsforskjeller i friluftsliv er et utfordrende felt som vil kunne bryte ned forestillingene om friluftsliv som en enhetlig praksis og fortolkningsverden i norsk kultur. Her har jeg antydet at det både er snakk om forskjeller mellom menn, mellom kvinner og menn, så vel som om forskjeller mellom kvinner.

\section{Avslutning}

Gjennom fortellingene om »den norske turkulturen « formidles det et bilde av norske kvinner og menn som både naturkjære og naturnære turgåere. Samtidig formidles det et mytelignende budskap om det norske samfunnet som et egalitært samfunn, og av friluftsliv som èn bestemt måte å forholde seg til naturen på som samtidig konstituerer norsk nasjonal identitet. Ved å sette tur- og friluftsliv slik det leves og oppleves av kvinner og menn i et samfunn som ofte betraktes som perifert i forhold til det norske samfunnet - i Finnmark $i$ sentrum, har jeg kommet på sporet av et mangfold av praksiser og opplevelser - av flere turkulturer eller friluftslivsstiler, som vanskelig vil kunne bringes til konsensus. Her har jeg identifisert et dynamisk og relasjonelt tur- og friluftsliv som skapes og omdannes 
i skjæringsfeltene mellom lokale høstingstradisjoner, »nasjonalt « overskuddsliv og globale trender. Jeg har bevisst gått inn i gråsonene der friluftslivet debatteres $\mathrm{i}$ ord og handlinger, og vektlagt kontraster og forskjellighet som baserer seg dels på at de to kjønn har ulik erfaringsbakgrunn, fortolkningsramme og posisjon i (lokal)samfunn og friluftsliv, dels på forskjellighet som skapes i en sosiokulturell kontekst der det asymmetriske forholdet mellom etniske grupper og mellom »sentrum « og »periferi «, mellom »sør« og »nord «, mellom det nasjonale og det lokale/regionale tillegges stor forklaringsverdi og betydning. Slik har jeg gitt et omriss av friluftsliv som en arena for produksjon av et mangfold av distinkte identiteter gjennom skaping og vedlikehold av kontraster. Samtidig har jeg kritisert norsk forskning om friluftsliv for å være både kjønnsblind, og blind for den betydning konteksten har for hvordan friluftsliv leves og oppleves.

Verken lokal, nasjonal eller global kultur - eller turkulur - finnes som klart definerbare, avgrensbare og statiske størrelser. Gjennom friluftsliv maktet byborgerskapet rundt århundreskiftet å definere - ikke bondetradisjonene eller folkelivet i fjellet som »det norske « - men sine egne fortolkninger av dette folkelivet som felles nasjonal kultur. De maktet å gi noe som var lokal livspraksis $\mathrm{i}$ en bestemt tidsperiode, status av å være nasjonal. Med referanse til enhetsmyten kan en stille spørsmål som: Er det nødvendigvis slik at forståelsen av friluftsliv som mangfoldig og dynamisk sosial og kulturell praksis nødvendigvis innebærer en fullstendig oppløsning eller fragmentering av ethvert grunnlag for fellesskap, felles forståelse og felles referanseramme? Innebærer det sammenfall av nasjonal identitet (jfr Nedrelid 1992)? Eller er det i de »små fortellinger« fra tur- og friluftsliv et kritisk potensiale som gir bilder av at både lokale, regionale og nasjonale fellesskap er basert på mangfold og konflikt, og ikke på enhet og likhet? Dersom vi tar utgangspunkt i de komplekse sosiale systemer og relasjoner vi som enkeltpersoner inngår i, kan kulturelle fellesskap som »det nasjonale« eller »det lokale« framstå både som inkonsistente og konfliktfylte; som en kombinasjon av mønster og kaos. Sannsynligvis er det nettopp slik at det er det som gjør kulturer - og i denne sammenhengen tur- og friluftsliv, til levende og nyskapende fellesskap. Studiet av friluftsliv i Finnmark viser at verken lokale, regionale eller nasjonale fellesskap er en garanti for ensartethet. Det kan være interessant å undersøke nærmere hvorvidt Finnmark for eksempel kan være sentrum for nyskapende krefter? Eller hvorvidt »sentrum« kan ha noe å lære av situasjonene i Finnmark? Er det nødvendigvis slik at samfunnsmessige endringer til »alle tider« har utspring i sentrum?

Slik jeg ser det, kan tur- og friluftsliv i 1990-årenes Finnmark, oppfattes som et prisme der ulike utviklingstendenser brytes og tydeliggjøres; som et komprimert uttrykk for en mangfoldighet av natur-, kvinne- og mannssyn i sen-moderne samfunn. Det skjer samtidige og motsatte endringstendenser; både en $\varnothing \mathrm{kt}$ vektlegging av lokale tradisjoner samtidig som globaliserende trender vinner innpass. Natur og turliv representerer både frihet, erobring, utvikling og framskritt, så vel som tradisjon, kontinuitet og faste holdepunkter i en omskiftelig samtid. Friluftsliv forutsetter et samfunn som er spesialisert og fremmedgjort i forhold til naturen som materiell ressurs, samtidig som folk kan søke tilbake til naturen for å »finne seg selv « i sin fritid. Tur- og friluftsliv er både et resultat av og en motstand mot modernisering og indu- 
strialisering. Konsekvensene av intensiv utnytting av lokale ressurser både i nærings- og fritidssammenheng er i løpet av de siste tiårene blitt stadig mer åpenbare. Økt ferdsel, utnytting og belastning fører til trivsel, rekreasjon og god helse, men også til slitasje- og forurensningsproblemer som igjen $\varnothing$ ker kravene til vern og reguleringer. Oppfatninger av Finnmarksnaturen som fritt tilgjengelige og »evigvarende « ressurser, er i ferd med å vike for en økende erkjennelse av at de enorme viddeområdene kan bli, eller allerede må betraktes som, en knapphetsressurs. Økende interesse for friluftsliv kombinert med $\varnothing \mathrm{kt}$ turisme, fører til økt press på utnyttelsen av lokale ressurser - ressurser som tidligere var forbeholdt lokalbefolkningen. Spenning mellom allmennhetens - hele den norske befolkningens adgang til Finnmarksnaturens ressurser og lokalbefolkningens behov, vil i framtida kunne føre til økte konflikter. Sen-modernitetens tur- og friluftsliv foregår med andre ord både $\mathrm{i}$ et livgivende produksjonslandskap, $i$ et rekreasjons- og opplevelseslandskap og i et truet landskap. Natur og friluftsliv spiller dessuten en viktig rolle for å skille praktisk og symbolsk mellom kvinnelige og mannlige virksomhetsområder. Jeg har antydet endringer som peker i retning av at friluftsliv i $\varnothing$ kende grad kan være med på å sprenge grenser for hva det er kulturelt mulig for kvinner å gjøre, samtidig som det kan bidra til å befeste en dyptliggende forestilling om at det eksisterer uoverstigelige forskjeller mellom kjønnene. Mens 1970-tallets debatter om friluftslivets ideologiske grunnlag og innhold var noe som opptok filosofer og pedagoger (Næss 1973, Faarlund 1974, Breivik 1978, 1979), er dette i 1980- og 90-tallets Finnmark samtale- og forhandlingstema hvor folk flest deltar. Det er muligens slik at de brytninger jeg skisserer ikke er spesielle for Finnmark, men at de blir tydeligere i utkantsamfunn hvor endringsprosessene komprimeres i tid og rom.

Et hovedpoeng som kan trekkes ut av de perspektiver jeg har trukket opp, er de utfordringene som ligger i det å utforske og avklare hvordan friluftslivets praksiser og fortolkninger er relatert til historiske, kulturelle og sosiale forhold, samt hvordan de blir gjenskapt og forandret i ulike kontekster. $\AA$ unders $\emptyset$ ke nærmere hvordan og hvorfor det kan være flere måter å oppleve og fortolke friluftsliv på; oppfatninger som samtidig kan være innbyrdes motstridende, men likevel rasjonelle og »riktige « utfra den sosiale og kulturelle kontekst friluftslivet, og de kvinner og menn som utøver det, inngår i, rommer nykapende potensialer i norsk friluftslivsforskning. Et slikt perspektiv åpner for at en og samme tur kan oppleves forskjellig alt etter utøverens sosiale og kulturelle bakgrunn, alder og kjønn. Der èn ser samiske kulturminner i landskapet, ser en annen et »perfekt « jaktterreng, mens en tredje kanskje er opptatt av landskapets lys og farger, formasjoner og linjer. »Ytre« sett kan de tre være på den samme turen samtidig og utføre tilnærmelsesvis identiske handlinger, men deres fortolkningsrammer er forskjellige. I eget arbeid har jeg valgt å analysere tur- og friluftsliv utfra et hverdagslivsperspektiv som knytter kvinners og menns måter å handle og tenke på til ytterst konkrete sosiale forhold. Det er en tilnærmingsmåte som åpner for å studere friluftsliv i relasjon til aktivitet på andre livsområder; for eksempel arbeidsliv, familieliv og nærmiljø. Det relasjonelle perspektivet gjør det også mulig å gripe samhandling, samarbeid og konflikt, arbeids- og oppgavefordeling mellom kvinner og menn. Slik blir det mulig å synliggjøre kvinners aktiviteter, be- 
hov og fortolkningsrammer som forskjellig fra og i relasjon til menns (Pedersen 1992, 1994).

En fortolkende og kulturanalytisk tilnærming innebærer samtidig en grunnleggende refleksivitet og en erkjennelse av at både samfunnsvitenskapene og forskeren er en del av den sosiale verden han/hun studerer. Slik refleksivitet har hittil vært fraværende i norsk friluftslivsforskning. Dersom det overordnede perspektivet er å jakte på enhetlige trekk ved norsk friluftsliv, vil det være lagt sterke føringer på forskerens bevissthet slik at betydningsfulle folkelige oppfatninger og iboende motsetninger $i$ friluftsliv står $\mathrm{i}$ fare for å bli tilslørt, uutforsket og underkommunisert. Nærhet og identifikasjon er viktige forutsetninger for innsikt. Men uten begreper om at det kan finnes kvalitativt anderledes fortolkninger av hva som er »det gode turliv«, og av hva som bør betegnes som friluftsliv, er det fare for at en som forsker blir »homeblind $\ll$ og mister den nødvendige kritiske og analytiske distanse. Både etnosentrisme og moralisme vil, slik jeg ser det, lett kunne forkomme i friluftslivsforskningen på grunn av forskernes ofte sterke identifisering med det emnet han studerer (det er sjelden en hun), og den emosjonelle ladning friluftsliv har i norsk kultur. Samtidig eksisterer det få arenaer for åpen faglig debatt ${ }^{19}$. I friluftslivsforskningen er det gode grunner til å minne om at

»En vanlig fallgrop i all kulturforskning ligger i att man alltför stärkt betonar harmoni, endräkt, sådant som människor delar och som gör dem lika. (...) Speciellt i studiet av komplexa samhällen som vårt eget bör man akta sig för att förutsätta alltför mycket homogenitet, ens bland människor som delar kultur.« (Ehn og Löfgren 1982:16).

I stedet for å fors $\varnothing \mathrm{ke}$ å finne fram til et entydig innhold i de begreper vi omgir oss med og bruker både $\mathrm{i}$ hverdagslivet og $\mathrm{i}$ forskningen, er det nødvendig å utforske det relasjonelle, flerdimensjonale og motsetningsfylte i begreper som kvinnelighet, mannlighet og friluftsliv. Slik åpnes det for deskripsjonspluralisme, tolknings- og forklaringsmangfold i forståelsen av tur- og friluftsliv i vår samtid. Slik blir det også mulig å ta hensyn til folks egne kategorier og virkelighetsforståelser i debattene om hva slags livsformer som ivaretar gjensidighet, likeverd og respekt mellom kvinner og menn, samtidig som en søker å sikre både $\varnothing$ kologisk, $\varnothing$ konomisk, sosial og kulturell bærekraft.

\section{Noter}

1. Jeg ønsker å rette en stor takk til alle de kvinner og menn som har delt sine turerfaringer med meg, til førsteamanuensis Siri Gerrard, Norges fiskerihøgskole for inspirerende veiledning og støtte i alle deler av prosjektet, kollegaer ved Høgskolen i Finnmark for verdifulle kommentarer underveis i arbeidet, og til Norges forskningsråd og Høgskolen i Finnmark som har finansiert det arbeidet som denne arikkelen inngår i.

2. Feltarbeidet er gjennomført i et lokalsamfunn i Norges nordligste fylke, Finnmark på begynnel-

sen av 1990-tallet. Gjennom feltarbeidet har jeg fulgt grupper av kvinner og menn i forskjellige former for friluftsliv, samtidig som jeg har fors $\varnothing \mathrm{kt}$ å fange inn hvilken betydning tur- og friluftsliv spiller i det lokale hverdagslivet. I Finnmark, som er lokalisert omkring 70 breddegrad,bor det idag omlag 75.000 innbyggere på et areal større enn Danmark (omlag 1,6 innbyggere pr $\mathrm{km}^{2}$ ). Landsdelen har gjennom flere hundre år vært en møteplass for forskjellige etniske grupper; samer, finnlendere/kvener, russere og nordmenn. 
3. FAFO-unders $\varnothing$ kelsen ble utført av Fagbevegelsens senter for forskning på oppdrag fra Norges idrettsforbund, Norges bedriftsidrettsforbund, Kultur- og Vitenskapsdepartemenetet og Norsk kommuneforbund.

4. Friluftslivets fellesorganisasjon (FRIFO) er en landsomfattende sammenslutning av 13 forskjellige friluftslivsorganisasjoner; der blant annet Den norske turistforening, Norges orienteringsforbund, Norges speiderforbund, Norges Jeger- og Fiskerforbund, Norges turmarsjforbund er med.

5. Riktignok finnes det forskjeller i forskningen, uten at disse rokker ved det dominerende enhetsperspektivet. Mens for eksempel Nedrelid (1988) og Faarlund (1987) viser at friluftslivets betydning for den nasjonale identitetsdanningen er et fenomen som vokser fram på slutten av 1800-tallet, hevder Christensen (1994) å kunne spore den nasjonale identitetsdanningen og dens koblinger til vinteraktiviteter i friluft - til skiidrett - tilbake til 16-1700 tallet.

6. Unders $\varnothing$ kelsen ble referert i norske aviser sommeren 1995. Jeg kan dessverre ikke referere direkte til unders $\varnothing$ kelsen som er utført av Markedsog Media Instituttet A/S fordi den kun er til internt bruk i Den norske turistforening, og derfor ikke tilgjengelig.

7. Siden den første snøscooteren ble introdusert i reindrifta i 1964, har snøscooteren revolusjonert, ikke bare livsformene for den samiske befolkningen. I fire-fem vintermåneder er snøscooteren viktigste fritidsaktivitet for omlag halvparten av befolkningen. Snøscooteren har gjort det mulig i løpet av et par timer å nå områder som tidligere i hovedsak var tilgjengelig for den samiske befolkningen, i hvert fall vinterstid (Pedersen 1993a).

8. Frykman og Löfgren (1979) bruker ikke begrepet friluftsliv. I et senere arbeid gjør de det (Ehn, Frykman og Löfgren 1993).

9. Dette har sammenheng med sosial mobilitet og store samfunnsmessige endringer over et relativt kort tidsrom. Det er ikke bare slik at det oppstår motsetninger mellom generasjoner. Også enkeltindivider kan oppleve store endringer i eget liv, som for eksempel endringer i status fra å være skolelev, til å bli husmor, student, leder i arbeidslivet, eller fra å være fisker, til å bli industriarbeider, elev ved voksenopplæring, student og kanskje sosialarbeider. Begreper som finnmarking, lokalbefolkning, tilflytter og »søring « er lite avgrensbare kategorier der det stadig er mulig å forhandle om innholdets relevans. Det finnes i dag mindre klare sammenhenger enn før mellom etnisk tilhørighet, $\varnothing$ konomisk tilpasning og folks bruk av naturen.

10. Beregnet på grunnlag av medlemsoversikt i Den norske turistforening (1994) Foreningsnytt $\mathrm{nr} 4$, s.8.

11. Tradisjonelt har fisket etter laks i for eksempel Altaelva foregått med stengsler der en ledet laksen inn i garn ved hjelp av gjerder som var satt ut i elva. Senere har den viktigste formen for lokalt fiske vært slukfiske. Siden midten av 1800-tallet har engelske og skotske Lorder hvert år leid hele og i de senere år deler, av Altaelva for å fiske laks. Slik ble også laksefisket med flue innført. Å være roer for »utlendingene « har vært en prestisjefylt bijobb for speiselt dyktige kjennere av elva. Slike bes $ø \mathrm{k}$ er det imidlertid bare en avgrenset kjerne av lokalbefolkningen som direkte har kontakt med eller kjenner til når foregår.

12. Den tradisjonelle lokale form for rypejakt har vært snarefangst eller st $ø$ kkjakt (jakt med gevær uten hund). Rypejakt med hund er fortsatt et stridstema i enkelte lokalsamfunn.

13. I studentmiljøet ved Høgskolen i Finnmark er det dessuten $\varnothing$ kende interesse for (innendørs)klatring og telemarkskjøring, aktiviteter som også kommer inn under denne kategorien. Finnmarks store viddeområder innebærer imidlertid at de naturmessige forutsteningene for disse aktivitetene ikke er de aller gunstigste.

14. Den norske stat eier 96 prosent av grunnen i Finnmark. Siden konflikten om kraftutbyggingen i Altaelva rundt 1980-tallet, har et statlig utvalg vært i arbeid for å avklare den samiske befolkningens rettigheter til naturressursene i Finnmark. At utvalget ennå ikke har kunnet avgi sin innstilling, uttrykker hvor juridisk komplisert og politisk vanskelig sak dette er.

15. Dette er tema for en avhandling i sosialantropologi som kollega Kari Heitmann ved Høgskolen i Finnmark arbeider med. Takk til Kari som tydeliggjorde analysen av forholdet mellom modernitet og tradisjon.

16. Det eksisterer en egen moltelov som gir de fastboende i Finnmark enerett til moltene som vokser innenfor fylkets grenser. Loven om motorisert ferdsel i utmark gir befolkningen i Finnmark og Nord-Troms muligheter til å kjøre snøscooter fritt i godkjente løyper. Ellers i landet er all rekreasjonskjøring med motorkjøretøy forbudt.

17. Her kan det, slik jeg ser det, trekkes en parallell til 1970-tallets $\varnothing$ kofilosofiske, samfunnskritiske og motkulturelle bevegelse innen friluftslivsforskning og formidling (jfr Næss 1973, Faarlund 
1954, Breivik 1978, 1979). Motstanden mot indsutrivektssamfunnet ble særlig markert gjennom en debatt om friluftslivsutstyr der valg av ull, bomull og treski kom til å bli meningsbærerende symboler for et $» \varnothing$ kobevisst $«$ og ansvarsfullt friluftsliv i skarp motstening til den som velger kunstfiber og glassfiberski.

18. Hvordan snøscooteren brukes i markeringen av lokal kultur aktualiserer spørsmålet om tid: Hvor gammelt må et formelement være før det kan få betegnelsen »lokal kultur «? Vanligvis er det noe som kan sies å ha status av å være noe opprinnelig; nærmest et slags urelement. Hvordan snøscooteren er blitt inkludert som en del av lokal kultur har, slik jeg ser det, sammenheng med at den fyller en rekke forskjellige behov. Ikke minst er det slik at snøsccoteren gjør det mulig (særlig for menn) å videreføre det tradisjonelle og frie livet i utmarka til tross for den tids- og stedsbinding lønnsarbeidet innebærer. Snøscooteren så og si opphever tids- og romdimensjonene som tidligere la sterke begrensninger på folks muligheter til ferdsel og kommunikasjon (Pedersen 1993).
19. Underfortsått er det her en kritikk av den nasjonalitetsorienterte froskningen fordi den spiller en viktig legitimerende og samfunnsbevarende rolle (jfr Kaltenborn 1994). Enkelte grupperinger i samfunnet vil kunne ha stor interesse i at »enhetsmyten « opprettholdes: Det gir for eksempel friluftslivets organisasjoner en veldig styrke å vite at de representerer »det norske folk «. Det gir samfunnsmessig og politisk legitimitet, samt berettigelse til offentlig støtte. Styrken ligger kort og godt i det at de kan hevde at de forvalter de manges interesser i kampen for å bevare »felles « turtradisjoner, kulturarv og nasjonal identitet. Å problematisere friluftslivet, eller å stille kritiske spørsmål ved den dominerende forståelse forskningen, forvaltningen og organisasjonene bygger på, vil lett kunne bli oppfattet som å vanhellige en nasjonal helligdom. Under overskriften »Ligg unna skituren!« oppfordrer for eksempel journalist Markus Markusson i Dagbladet (20.11.1991) forskere om ikke å forske på hva søndagsturen betyr for oss, fordi den $» . .$. er noe privat og skjørt og kan briste ...«.

\section{Referanser}

Archetti, Edvardo (1984) Om maktens ideologi - en krysskulturell analyse. I Klausen, Arne Martin red. Den norske varemåten. Antropologisk sфkelys på norsk kultur. Cappelen, Oslo

Breivik, Gunnar (1990) Idretten mot år 2000. Foredrag på konferansen »Friluftsliv og reiseliv«, Oppdal 12,-14.februar 1990. Muntlig kilde.

Breivik, Gunnar (1979) Friluftsliv. Noen filosofiske og pedagogiske aspekter. Kompendium nr. 50, Norges idrettshøgskole, Oslo

Breivik, Gunnar (1986) Det blir trongare om plassen på arenaen for friluftsliv. I Syn og Segn, nr 2:115124

Breivik, Gunnar (1978) To tradisjoner i norsk friluftsliv. I Breivik, Gunnar og Løvmo, Håkon (red) Friluftsliv - fra Fridtjof Nansen til våre dager. Universitetsforlaget, Oslo, s.7-16

Christensen, Olav (1993) Skiidrett før Sondre. Vinterveien til et nasjonalt selvbilde. Ad Notam, Oslo

Den norske turistforening (1993) Friluftsliv og glede. Strateginotat. Oslo

Direktoratet for naturforvaltning (1991) Friluftsliv mot år 2000. Forslag til handlingsplan. DN-rapport nr. 3, Trondheim

Drivenes, Einar-Arne, Hauan, Marit A., Wold, Helge A. (red) (1994) Innledning: Den besvarlige identiteten. I Nordnorsk kulturhistorie, Bind 2. Gyldendal, Oslo, s.9-17

Dølvik, Jon-Erik m.fl. (1988) Kluss $i$ vekslinga. Fritid, idrett og organisering. Fagbevegelsens senter for forskning, Oslo

Ehn, Billy, Frykman, Jonas og Löfgren, Orvar (1993) Försvenskningen av Sverige. Det nationellas förvandlingar. Natur och kultur, Stockholm

Ehn, Billy og Löfgren, Orvar (1982) Kulturanalys. Et etnologisk perspektiv. Liber, Malmö

Finansdepartementet (1972/73) Spesialanalyse $n r .6$ : FRILUFTSLIV. Oslo

Frislid, Ragnar (1983) Fritid i friluft. I Norges Kulturhistorie, bind 7:163-178

Frykman, Jonas og Löfgren, Orvar (1979) Den kulturskapade människan. Liber, Malmö

Faarlund, Nils (1971) Friluftsliv. I Idrettens leksikon, Bind I. Teknisk forlag A/S, Oslo, s. 464-487 
Faarlund, Nils (1987) Askeladden. I Ydegaard, Torbjørn (red) Om å gripe fjellet - og bli grepet av fjellet. En vennebok om friluftslivet og Nils Faarlund. Nordisk Forum for Vejledning i Natur- og Friluftsliv, s.13-20

Faarlund, Nils (1974) Hva - Hvordan - Hvorfor. Friluftsliv. Kompendium nr.32, Norges idrettshøgskole, Oslo

Gaski, Lina (1993) Rettigheter og ressurser i lokalsamfunnsperspektiv. I Forvaltningen av samiske interesser i 1990-årene. Utredning fra en arbeidsgruppe, Institutt for samfunnsvitenskap. Universitetet i Tromsø, s. 117-164

Goksøyr, Matti (1994) Nasjonal identitetsbygging gjennom idrett og friluftsliv. I Nytt Norsk Tidsskrift nr 2: 182-193

Gullestad, Marianne (1990) Naturen i norsk kultur. Noen foreløpige refleksjoner. I Frønes, Ivar og Sørensen, Trine D. (red.) Kulturanalyse, Oslo

Hage, Torild red. (1988) Kvinner og friluftsliv. Rapport fra en idèdugnad 9.2.1988. Direktoratet for naturforvaltning, Trondheim

Hargreaves, Jennifer (1994) Sporting females. Routledge, London and New York

Hylland Eriksen, Thomas (1993) Typisk norsk. Essays. C.Huitfedt Forlag A.S, Oslo

Kaltenborn, Bjørn P. (1994) Bruk og kast eller døve $\emptyset$ rer: Om forvaltningens bruk av forskningsresultater. I Friluftsliv og effekter. DN-notat nr 7, s. 329333

Kaltenborn, Bjørn P. (1993) Forskning om friluftsliv. I Kaltenborn, Bjørn P. og Vorkinn, Marit red. Vårt friluftsliv. Aktiviteter, miljøkrav og forvaltningsbehov. Norsk institutt for naturforskning. Temahefte nr 3, Lillehammer

Klepp, Asbjørn og Torsen, Liv Emma red. (1993) Den mangfoldige fritiden. Ad notam, Oslo

Kramvig, Britt (1995) For fulle seil inn i framtida. I Ottar nr 2, Troms $\varnothing$, s.61-67

Long, Litt Woon (1993) Hvordan jeg lærte å gå på tur. Norsk friluftsliv sett utenfra. I Klepp, Ingun Grimestad og Svarverud, Rune red. Idrett og fritid $i$ kulturbildet. Universitetet i Oslo, Oslo, s.187-194

Messner, Michael A. (1990) Men Studying Masculinity: Some Epistemological Issues. In Sociology of Sport Journal, 7, pp.136-153.

Moore, Henrietta L. (1988) Feminism and Anthropology. Polity Press, Oxford

Nedrelid, Tove (1992) Friluftslivet og vår nasjonale selvforståelse. I Nytt Norsk Tidsskrift nr 2;281-288

Nedrelid, Tove (1988) Naturbruk som nøkkelsymbol. I Dugnad nr. 1, volum 14, s.57-74

Nedrelid, Tove (1991) Use of Nature as a Norwegian
Characteristic. Myths and reality. I Ethnologica Scandinavica, Vol. 21, s. 20-33

Norges Offentlige Utredninger (1994) Bruk av land og vann i Finnmark $i$ historisk perspektiv. Justisog politidepartementet, Oslo

Norges Offentlige Utredninger (1993) Rett til og forvaltning av land og vann i Finnmark. Justis- og politidepartementet, Oslo

Næss, Arne (1973) Økologi, samfunn og livsstil. Universitetsforlaget, Oslo

Ortner, Sherry B. (1973) Key-symbols. I American Anthropologist no 75, s.1338-1346

Pedersen, Kirsti (1994b) Outdoor Life in Women's Lives. I Kvinner - en utfordring til idretten? Rapport fra en konferanse i anledning OL'94 i Lillehammer. Arbeidsnotat 2, Sekretariatet for kvinneforskning, Norges forskningsråd, Oslo, s.139-152.

Pedersen, Kirsti (1993a) Gender, Nature and Technology: Changing Trends in $»$ Wilderness Life « in Northern Norway. I Riewe, R. and Oakes, J.(red) Human Ecology: Issues in the North, vol .II University of Alberta, Edmonton, s. 53-66.

Pedersen, Kirsti (1993b) Kvinnerettede opplacringstilbud i friluftsliv. Forskningsrapport nr 3, Alta lærerhøgskole, Alta

Pedersen, Kirsti (1993c) Kultur- og tradisjonsformidling gjennom vinteraktiviteter. Arbeidsnotat til Prosjektet »Vinterunger i Finnmark«, arrangert av Statens utdanningskontor i Finnmark, Alta lærerhøgskole

Pedersen, Kirsti (1992) Friluftsliv og hverdagsliv. Noen foreløpige refleksjoner over kvinners og menns ulike vilkår for deltakelse. I Sjong, Mari-Lise (1992) Geografi og kjoerlighet. Skrifter fra Norske Geografers Forening, Serie no 3:138-145, Røros

Pedersen, Kirsti og Viken, Arvid (under publisering) From Sami Nomadism to Global Tourism. I Price, Martin (red) People and Tourism in Fragile Environments. John Wiley and Son, Ltd. London

Richardson, Heidi (1994) Kraftanstrengelse og ensomhet. En analyse av det norske friluftslivets kulturelle konstruksjoner. Hovedoppgave i etnologi, Universitetet i Bergen

Rudie, Ingrid (1984) Innledning. I Rudie, I. red. Myk start - hard landing. Universitetsforlaget, Oslo

Skirbekk, Gunnar (1981) Nasjon og natur. Eit essay om den norske veremåten. I Bjugn m.fl red. Eit våpen mot vanen. Det norske samlaget, Oslo

Skirbekk, Gunnar (1985) Samfunnsvitenskapenes vitenskapsfilosofi. I Johannesen, Kjell S. Glimt fra vitenskapsfilosofiens hovedområder. Sigma forlag, Berge, s.131-150 
Stortingsmelding nr 40 (1986-87) Om friluftsliv. Miljøverndepartementet, Oslo

Tjelmeland, Halvor (1994) Det seinmoderne NordNorge. Om tenesteyting, tettstader og tusseladdar. I Drivenes, E-A, Hauan, M.A., Wold, H.A. red. Nordnorsk kulturhistorie. Gyldendal, Oslo, s.346387

Turner, Victor (1967) The Forest of Symbols. Cornell University Press, Ithaca

Urry, John (1987) The Tourist Gaze. Leisure and Travel in Contemporary Societies. Sage, London von Wright, Georg Henrik (1993) Myten om fremskrittet. Cappelens upopulære skrifter, Oslo

Vaagbø, Olav (1993) Den norske turkulturen. Friluftslivets fellesorganisasjon, Oslo
Witoszek, Nina (1991) Der kultur mфter natur: Tilfellet Norge. I Samtiden, nr. 4, s. 11-19

Østerberg, Dag (1984) Naturdyrkelse. I Østerberg, Dag og Engelstad, Karl-Fredrik (1984) Samfunnsformasjonen. En innfфring i sosiologi. Pax, Oslo, s. 399-402

Aarnes, Sigurd Aa. (1991) »Hu hei kor er det vel friskt og lett uppå fjellet! « I Nytt norsk tidsskrift, nr 1, s. 78-83

Aas, Øystein og Aasetre, Jørun (1994) Bærplukking i Norge - en truet friluftslivsaktivitet? I Emmelin, Lars red. (1994) Nordiskt seminarium om friluftslivsforskning. Nordplan, rapport nr 3, Stockholm, s.61-72 